\title{
Developing a Machine Learning Model to Predict Severe Chronic Obstructive Pulmonary Disease Exacerbations: Retrospective Cohort Study
}

Siyang Zeng ${ }^{1}$, MS; Mehrdad Arjomandi ${ }^{2,3}$, MD; Yao Tong ${ }^{1}$, MSc; Zachary C Liao ${ }^{1}$, MPH, MD; Gang Luo ${ }^{1}$, DPhil

${ }^{1}$ Department of Biomedical Informatics and Medical Education, University of Washington, Seattle, WA, United States

${ }^{2}$ Medical Service, San Francisco Veterans Affairs Medical Center, San Francisco, CA, United States

${ }^{3}$ Department of Medicine, University of California, San Francisco, CA, United States

Corresponding Author:

Gang Luo, DPhil

Department of Biomedical Informatics and Medical Education

University of Washington

UW Medicine South Lake Union, 850 Republican Street, Building C, Box 358047

Seattle, WA, 98195

United States

Phone: 12062214596

Fax: 12062212671

Email: gangluo@cs.wisc.edu

\section{Abstract}

Background: Chronic obstructive pulmonary disease (COPD) poses a large burden on health care. Severe COPD exacerbations require emergency department visits or inpatient stays, often cause an irreversible decline in lung function and health status, and account for $90.3 \%$ of the total medical cost related to COPD. Many severe COPD exacerbations are deemed preventable with appropriate outpatient care. Current models for predicting severe COPD exacerbations lack accuracy, making it difficult to effectively target patients at high risk for preventive care management to reduce severe COPD exacerbations and improve outcomes.

Objective: The aim of this study is to develop a more accurate model to predict severe COPD exacerbations.

Methods: We examined all patients with COPD who visited the University of Washington Medicine facilities between 2011 and 2019 and identified 278 candidate features. By performing secondary analysis on 43,576 University of Washington Medicine data instances from 2011 to 2019, we created a machine learning model to predict severe COPD exacerbations in the next year for patients with COPD.

Results: The final model had an area under the receiver operating characteristic curve of 0.866 . When using the top 9.99\% (752/7529) of the patients with the largest predicted risk to set the cutoff threshold for binary classification, the model gained an accuracy of $90.33 \%$ (6801/7529), a sensitivity of 56.6\% (103/182), and a specificity of 91.17\% (6698/7347).

Conclusions: Our model provided a more accurate prediction of severe COPD exacerbations in the next year compared with prior published models. After further improvement of its performance measures (eg, by adding features extracted from clinical notes), our model could be used in a decision support tool to guide the identification of patients with COPD and at high risk for care management to improve outcomes.

International Registered Report Identifier (IRRID): RR2-10.2196/13783

(J Med Internet Res 2022;24(1):e28953) doi: 10.2196/28953

\section{KEYWORDS}

chronic obstructive pulmonary disease; machine learning; forecasting; symptom exacerbation; patient care management 


\section{Introduction}

\section{Background}

In the United States, chronic obstructive pulmonary disease (COPD) affects $6.5 \%$ of adults [1] and is the fourth leading cause of death, excluding COVID-19 [2]. Each year, COPD causes 1.5 million emergency department (ED) visits, 0.7 million inpatient stays, and US \$32.1 billion in total medical cost [1]. Severe COPD exacerbations are those that require ED visits or inpatient stays [3], account for $90.3 \%$ of the total medical cost related to COPD [4], and often cause irreversible decline in lung function and health status [5-10]. Many severe COPD exacerbations (eg, $47 \%$ of the inpatient stays for COPD) are deemed preventable with appropriate outpatient care [3,11] because COPD is an ambulatory care-sensitive condition [12] A commonly used method to reduce severe COPD exacerbations is to place patients at high risk in a care management program for preventive care [13-15]. Patients at high risk can be identified prospectively using a predictive model [16]. Once a patient enters the care management program, a care manager will periodically contact the patient for health status assessment and to help coordinate health and related services. This method is adopted by many health plans, such as those in 9 of 12 metropolitan communities [13], and many health care systems. Successful care management can reduce up to $27 \%$ of the ED visits [14] and $40 \%$ of the inpatient stays [15] in patients with COPD.

However, because of limitations of resources and service capacity, only $\leq 3 \%$ of patients could enter a care management program [17]. Its effectiveness is upper bounded by these patients' risk levels, which are determined by how accurate the used predictive model is. Neither the stage of COPD nor having prior severe COPD exacerbations alone can predict a patient's risk level for future severe COPD exacerbations well [18,19]. Previously, researchers had built several models to predict severe COPD exacerbations in patients with COPD [20-53]. These models are inaccurate and suboptimal for use in care management because they missed more than $50 \%$ of the patients who will experience severe COPD exacerbations in the future, incorrectly projected many other patients to experience severe COPD exacerbations [20-22,53], used data unavailable in routine clinical practice [23-31,33,34,36,42-50,52], or were designed for patients who have different characteristics from typical patients with COPD [25-34]. In addition, most of these models predicted only inpatient stays for COPD. To better guide the use of care management, we need to predict both ED visits and inpatient stays for COPD, which only 2 of these models [34,36] do. In practice, once a model is deployed for care management, the prediction errors produced by the model would lead to degraded patient outcomes and unnecessary health care costs. Because of the large number of patients with COPD, even a small improvement in model accuracy coupled with appropriate preventive interventions could help improve outcomes and avoid many ED visits and inpatient stays for COPD every year.

\section{Objective}

This study aims to develop a more accurate model to predict severe COPD exacerbations in the next year in patients with COPD. To be suitable for use in care management, the model should use data available in routine clinical practice and target all patients with COPD.

\section{Methods}

\section{Ethics Approval and Study Design}

The institutional review board of the University of Washington Medicine (UWM) approved this secondary analysis study on administrative and clinical data.

\section{Patient Population}

In Washington state, the UWM is the largest academic health care system. The UWM enterprise data warehouse includes administrative and clinical data from 3 hospitals and 12 clinics. The patient cohort consisted of the patients with COPD who visited any of these facilities between 2011 and 2019. Using our prior method for identifying patients with COPD [54] that was adapted from the literature [55-58], we regarded a patient to have COPD if the patient was aged $\geq 40$ years and met $\geq 1$ of the 4 criteria listed in Textbox 1 . When computing the data instances in any year, we excluded the patients who had no encounter at the UWM or died during that year. No other exclusion criterion was used.

Textbox 1. The 4 criteria used for identifying patients with chronic obstructive pulmonary disease.

\section{Description of each of the 4 criteria}

- An outpatient visit diagnosis code of chronic obstructive pulmonary disease (International Classification of Diseases, Ninth Revision: 491.22, 491.21, 491.9, 491.8, 493.2x, 492.8, 496; International Classification of Diseases, Tenth Revision: J42, J41.8, J44.*, J43.*) followed by $\geq 1$ prescription of long-acting muscarinic antagonist (aclidinium, glycopyrrolate, tiotropium, and umeclidinium) within 6 months

- $\quad \geq 1$ emergency department or $\geq 2$ outpatient visit diagnosis codes of chronic obstructive pulmonary disease (International Classification of Diseases, Ninth Revision: 491.22, 491.21, 491.9, 491.8, 493.2x, 492.8, 496; International Classification of Diseases, Tenth Revision: J42, J41.8, J44.*, J43.*)

- $\quad \geq 1$ inpatient stay discharge having a principal diagnosis code of chronic obstructive pulmonary disease (International Classification of Diseases, Ninth Revision: 491.22, 491.21, 491.9, 491.8, 493.2x, 492.8, 496; International Classification of Diseases, Tenth Revision: J42, J41.8, J44.*, J43.*)

- $\quad \geq 1$ inpatient stay discharge having a principal diagnosis code of respiratory failure (International Classification of Diseases, Ninth Revision: 518.82, 518.81, 799.1, 518.84; International Classification of Diseases, Tenth Revision: J96.0*, J80, J96.9*, J96.2*, R09.2) and a secondary diagnosis code of acute chronic obstructive pulmonary disease exacerbation (International Classification of Diseases, Ninth Revision: 491.22, 491.21, 493.22, 493.21; International Classification of Diseases, Tenth Revision: J44.1, J44.0) 


\section{Prediction Target (Also Known as the Outcome or the Dependent Variable)}

Given a patient with COPD who had $\geq 1$ encounter at the UWM in a specific year (the index year), we used the patient's data up to the last day of the year to predict the outcome of whether the patient would experience any severe COPD exacerbation, that is, any ED visit or inpatient stay with a principal diagnosis of COPD (International Classification of Diseases, Ninth Revision: 491.22, 491.21, 491.9, 491.8, 493.2x, 492.8, 496; International Classification of Diseases, Tenth Revision: J42, $\mathrm{J} 41.8, \mathrm{~J} 44 .^{*}, \mathrm{~J} 43 . *$ ), in the next year (Figure 1).

Figure 1. The periods used to partition the training and test sets and the periods used to compute the prediction target and the features for a patient and index year pair.

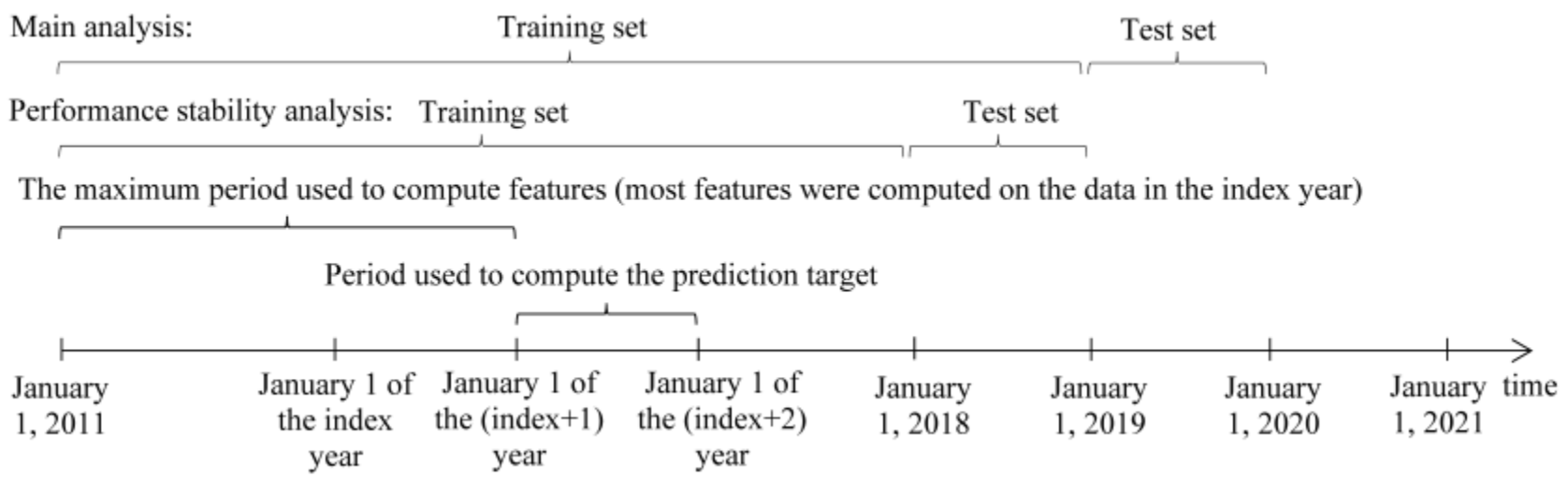

\section{Data Set}

We obtained a structured data set from the UWM enterprise data warehouse. This data set included administrative and clinical data relating to the patient cohort's encounters at the 3 hospitals and 12 clinics of the UWM from 2011 to 2020.

\section{Features (Also Known as Independent Variables)}

To improve model accuracy, we examined an extensive set of candidate features computed on the structured attributes in the data set. Table S1 of Multimedia Appendix 1 [3,18,28,30,50,59-83] shows these 278 candidate features coming from four sources: the known risk factors for COPD exacerbations $[3,18,28,30,50,59-72]$, the features used in prior models to predict severe COPD exacerbations [20-53], the features that the clinician ZCL in our team suggested, and the features used in our prior models to predict asthma hospital encounters [84,85]. Asthma shares many similarities with COPD. Throughout this paper, whenever we mention the number of a given type of item (eg, medication) without using the word distinct, we count multiplicity.

Each input data instance to the predictive model contained 278 features, corresponded to a distinct patient and index year pair, and was used to predict the outcome of the patient in the next year. For this pair, the patient's age was computed based on the age at the end of the index year. The patient's primary care provider (PCP) was computed as the last recorded PCP of the patient by the end of the index year. The percentage of the PCP's patients with COPD in the preindex year having severe COPD exacerbations in the index year was computed on the data in the preindex and index years. Using the data from 2011 to the index year, we computed 26 features: the number of years from the first encounter related to COPD in the data set, the type of the first encounter related to COPD in the data set, 7 allergy features, and 17 features related to the problem list. The other 251 features were computed on the data in the index year.

\section{Data Analysis}

\section{Data Preparation}

Using the data preparation approach used in our papers [84,85], we identified the biologically implausible values, replaced them with null values, and normalized the data. As outcomes came from the next year, the data set had 9 years of effective data (2011-2019) over a time span of 10 years (2011-2020). To reflect future model use in clinical practice and to evaluate the impact of the COVID-19 pandemic on patient outcomes and model performance, we conducted two analyses:

1. Main analysis: we used the 2011-2018 data instances as the training set to train models and the 2019 data instances as the test set to assess model performance.

2. Performance stability analysis: we used the 2011-2017 data instances as the training set to train models and the 2018 data instances as the test set to assess model performance.

\section{Classification Algorithms}

We created machine learning classification models using Waikato Environment for Knowledge Analysis (WEKA; version 3.9) [86]. WEKA is a major open source software package for machine learning and data mining. It integrates many commonly used machine learning algorithms and feature selection techniques. We examined the 39 classification algorithms supported by WEKA and listed in the web-based multimedia appendix of our paper [84], as well as Extreme Gradient Boosting (XGBoost) [87] implemented in the XGBoost4J package [88]. XGBoost is a classification algorithm using an ensemble of decision trees. As XGBoost only takes numerical features, we converted categorical features to binary features through one-hot encoding. In the main analysis, we used the training set and our formerly published automatic machine learning model selection method [89] to automate the selection of the classification algorithm, feature selection technique, data balancing method to deal with imbalanced data, and hyperparameter values among all applicable ones. Compared 
with the Auto-WEKA automatic machine learning model selection method [90], our method achieved an average of $11 \%$ (SD 15\%) reduction in model error rate and a 28 -fold reduction in search time. In the performance stability analysis, we used the same classification algorithm, feature selection technique, and hyperparameter values as those used in the final model of the main analysis.

\section{Performance Metrics}

As shown in the formulas, the performance of the models was evaluated with respect to the following metrics: accuracy (Table 1); sensitivity, also known as recall; specificity; positive predictive value (PPV), also known as precision; negative predictive value (NPV); and area under the receiver operating characteristic curve (AUC):

$$
\begin{aligned}
& \text { Accuracy }=(\mathrm{TP}+\mathrm{TN}) /(\mathrm{TP}+\mathrm{TN}+\mathrm{FP}+\mathrm{FN})(\mathbf{1}) \\
& \text { Sensitivity }=\mathrm{TP} /(\mathrm{TP}+\mathrm{FN})(\mathbf{2}) \\
& \text { Specificity }=\mathrm{TN} /(\mathrm{TN}+\mathrm{FP})(\mathbf{3}) \\
& \mathrm{PPV}=\mathrm{TP} /(\mathrm{TP}+\mathrm{FP})(\mathbf{4}) \\
& \mathrm{NPV}=\mathrm{TN} /(\mathrm{TN}+\mathrm{FN})(\mathbf{5})
\end{aligned}
$$

\begin{tabular}{|c|c|c|}
\hline Outcome class & Severe COPD ${ }^{\mathrm{a}}$ exacerbations in the next year & No severe COPD exacerbation in the next year \\
\hline Predicted severe COPD exacerbations in the next year & True positive & False positive \\
\hline $\begin{array}{l}\text { Predicted no severe COPD exacerbation in the next } \\
\text { year }\end{array}$ & False negative & True negative \\
\hline
\end{tabular}

where TP stands for true positive, TN stands for true negative, FP stands for false positive, and FN stands for false negative.

Table 1. The confusion matrix.

${ }^{\mathrm{a} C O P D}$ : chronic obstructive pulmonary disease

We computed the $95 \%$ CIs of the performance measures using the bootstrapping method [91]. We obtained 1000 bootstrap samples from the test set and computed the model's performance measures based on each bootstrap sample. This produced 1000 values for each performance metric. Their 2.5th and 97.5th percentiles provided the $95 \%$ CI of the corresponding performance measures. To depict the trade-off between sensitivity and specificity, we drew the receiver operating characteristic curve.

\section{Results}

\section{Distributions of Data Instances and Bad Outcomes}

The number of data instances increased over time. The proportion of data instances linked to bad outcomes remained relatively stable over time. The only exception was the sudden drop from $5.21 \%$ (369/7089) in 2018 to $2.42 \%$ (182/7529) in 2019 (Table 2), which resulted from the large drop in ED visits and inpatient stays for COPD in 2020 caused by the COVID-19 pandemic [92]. In the main analysis, 5.66\% (2040/36,047) of the data instances in the training set and $2.42 \%(182 / 7529)$ of the data instances in the test set were linked to severe COPD exacerbations in the next year. In the performance stability analysis, $5.77 \%(1671 / 28,958)$ of the data instances in the

\begin{tabular}{|c|c|c|c|c|c|c|c|c|c|}
\hline & Year & & & & & & & & \\
\hline & 2011 & 2012 & 2013 & 2014 & 2015 & 2016 & 2017 & 2018 & 2019 \\
\hline Data instances, $\mathrm{n}$ & 1848 & 2725 & 3204 & 4009 & 4875 & 5793 & 6504 & 7089 & 7529 \\
\hline $\begin{array}{l}\text { Data instances linked to severe COPD }{ }^{\mathrm{a}} \text { exacerbations } \\
\text { in the next year, } \mathrm{n}(\%)\end{array}$ & $\begin{array}{l}128 \\
(6.93)\end{array}$ & $\begin{array}{l}176 \\
(6.46)\end{array}$ & $\begin{array}{l}183 \\
(5.71)\end{array}$ & $\begin{array}{l}223 \\
(5.56)\end{array}$ & $\begin{array}{l}272 \\
(5.58)\end{array}$ & $\begin{array}{l}351 \\
(6.06)\end{array}$ & $\begin{array}{l}338 \\
(5.2)\end{array}$ & $\begin{array}{l}369 \\
(5.21)\end{array}$ & $\begin{array}{l}182 \\
(2.42)\end{array}$ \\
\hline
\end{tabular}
training set and $5.21 \%(369 / 7089)$ of the data instances in the test set were linked to severe COPD exacerbations in the next year.

Table 2. The distributions of data instances and bad outcomes over time.

${ }^{\mathrm{a}} \mathrm{COPD}$ : chronic obstructive pulmonary disease.

\section{Patient Characteristics}

Each patient and index year pair matched a data instance. For both the training set and the test set of the main analysis, when comparing the patient characteristic distributions between the data instances linked to severe COPD exacerbations in the next year and those linked to no severe COPD exacerbation in the next year, $P$ values were computed using the chi-square 2-sample test and the Cochran-Armitage trend test [93] for categorical and numerical characteristics, respectively (Tables 3 and 4).
In the training set of the main analysis, most patient characteristics exhibited statistically significantly different distributions between the data instances linked to severe COPD exacerbations in the next year and those linked to no severe COPD exacerbation in the next year. Exceptions occurred on the patient characteristics of having prescriptions of inhaled corticosteroid, long-acting beta-2 agonist (LABA), and long-acting muscarinic antagonist (LAMA) combinations $(P=.66)$; having prescriptions of phosphodiesterase-4 inhibitor $(P=.06)$; presence of diabetes $(P=.43)$; presence of eczema $(P=.30)$; presence of lung cancer $(P=.31)$; and presence of sinusitis $(P=.61)$. In the test set of the main analysis, most patient 
characteristics exhibited statistically significantly different distributions between the data instances linked to severe COPD exacerbations in the next year and those linked to no severe COPD exacerbation in the next year. Exceptions occurred on the patient characteristics of having private insurance $(P=.79)$; having prescriptions of LABA and LAMA combinations $(P=.54)$; having prescriptions of inhaled corticosteroid, LABA, and LAMA combinations $(P=.90)$; having prescriptions of phosphodiesterase-4 inhibitor $(P=.27)$; presence of allergic rhinitis $(P=.24)$; presence of anxiety or depression $(P=.08)$; presence of congestive heart failure $(P=.11)$; presence of diabetes $(P=.95)$; presence of eczema $(P=.08)$; presence of hypertension $(P=.05)$; presence of lung cancer $(P=.51)$; presence of obesity $(P=.25)$; presence of sinusitis $(P=.99)$; and presence of sleep apnea $(P=.22)$. 
Table 3. The patient characteristics of the data instances in the training set of the main analysis.

\begin{tabular}{|c|c|c|c|c|}
\hline Patient characteristic & $\begin{array}{l}\text { Data instances } \\
(\mathrm{N}=36,047), \mathrm{n}(\%)\end{array}$ & $\begin{array}{l}\text { Data instances linked to severe } \\
\text { COPD }^{\text {a }} \text { exacerbations in the next } \\
\text { year }(N=2040), n(\%)\end{array}$ & $\begin{array}{l}\text { Data instances linked to no severe } \\
\text { COPD exacerbation in the next year } \\
(\mathrm{N}=34,007), \mathrm{n}(\%)\end{array}$ & $P$ value \\
\hline Age (years) & & & & $<.001^{\mathrm{b}}$ \\
\hline $40-65$ & $18,793(52.13)$ & $1219(59.75)$ & $17,574(51.68)$ & $<.001$ \\
\hline$>65$ & $17,254(47.87)$ & $821(40.25)$ & $16,433(48.32)$ & $<.001$ \\
\hline Sex & & & & $<.001$ \\
\hline Female & $15,414(42.76)$ & 749 (36.72) & $14,665(43.12)$ & $<.001$ \\
\hline Male & $20,633(57.24)$ & $1291(63.28)$ & $19,342(56.88)$ & $<.001$ \\
\hline Race & & & & $<.001$ \\
\hline $\begin{array}{l}\text { American Indian or Alaska Na- } \\
\text { tive }\end{array}$ & $713(1.98)$ & $26(1.27)$ & $687(2.02)$ & $<.001$ \\
\hline Asian & $2092(5.8)$ & $144(7.06)$ & $1948(5.73)$ & $<.001$ \\
\hline Black or African American & $4795(13.3)$ & $524(25.69)$ & $4271(12.56)$ & $<.001$ \\
\hline $\begin{array}{l}\text { Native Hawaiian or other Pacific } \\
\text { Islander }\end{array}$ & $184(0.51)$ & $8(0.39)$ & $176(0.52)$ & $<.001$ \\
\hline White & $27,447(76.14)$ & $1330(65.2)$ & $26,117(76.8)$ & $<.001$ \\
\hline Other, unknown, or not reported & $816(2.27)$ & $8(0.39)$ & $808(2.37)$ & $<.001$ \\
\hline Ethnicity & & & & $<.001$ \\
\hline Hispanic & $857(2.38)$ & $53(2.6)$ & $804(2.36)$ & $<.001$ \\
\hline Non-Hispanic & 32,585 (90.39) & $1941(95.15)$ & $30,644(90.11)$ & $<.001$ \\
\hline Unknown or not reported & $2605(7.23)$ & $46(2.25)$ & $2559(7.53)$ & $<.001$ \\
\hline Current smoker & $16,952(47.03)$ & $1089(53.38)$ & $15,863(46.65)$ & $<.001$ \\
\hline Former smoker & $7367(20.44)$ & $345(16.91)$ & $7022(20.65)$ & $<.001$ \\
\hline Never smoker or unknown & $11,728(32.53)$ & $606(29.71)$ & $11,122(32.7)$ & $<.001$ \\
\hline \multicolumn{5}{|l|}{ Insurance } \\
\hline Private & $17,513(48.58)$ & $834(40.88)$ & $16,679(49.05)$ & $<.001$ \\
\hline Public & $29,598(82.11)$ & $1767(86.62)$ & $27,831(81.84)$ & $<.001$ \\
\hline Self-paid or charity & $1994(5.53)$ & $229(11.23)$ & 1765 (5.19) & $<.001$ \\
\hline \multicolumn{4}{|c|}{ Number of years from the first encounter related to COPD in the data set } & $<.001$ \\
\hline$\leq 3$ & $30,315(84.1)$ & $1566(76.76)$ & $28,749(84.54)$ & $<.001$ \\
\hline$>3$ & $5732(15.9)$ & $474(23.24)$ & $5258(15.46)$ & $<.001$ \\
\hline \multicolumn{5}{|l|}{ COPD medication prescription } \\
\hline $\mathrm{ICS}^{\mathrm{c}}$ & $13,327(36.97)$ & $1119(54.85)$ & $12,208(35.9)$ & $<.001$ \\
\hline SAMA $^{\mathrm{d}}$ & $9608(26.65)$ & $1042(51.08)$ & $8566(25.19)$ & $<.001$ \\
\hline $\mathrm{SABA}^{\mathrm{e}}$ & $22,549(62.55)$ & $1684(82.55)$ & $20,865(61.36)$ & $<.001$ \\
\hline SABA and SAMA combination & $7174(19.9)$ & $810(39.71)$ & $6364(18.71)$ & $<.001$ \\
\hline LAMA $^{\mathrm{f}}$ & $10,243(28.42)$ & $1001(49.07)$ & $9242(27.18)$ & $<.001$ \\
\hline LABA $^{\mathrm{g}}$ & $8904(24.7)$ & $842(41.27)$ & $8062(23.71)$ & $<.001$ \\
\hline LABA and LAMA combination & $426(1.18)$ & $40(1.96)$ & $386(1.14)$ & .001 \\
\hline
\end{tabular}




\begin{tabular}{|c|c|c|c|c|}
\hline Patient characteristic & $\begin{array}{l}\text { Data instances } \\
(\mathrm{N}=36,047), \mathrm{n}(\%)\end{array}$ & $\begin{array}{l}\text { Data instances linked to severe } \\
\text { COPD }^{\mathrm{a}} \text { exacerbations in the next } \\
\text { year }(\mathrm{N}=2040), \mathrm{n}(\%)\end{array}$ & $\begin{array}{l}\text { Data instances linked to no severe } \\
\text { COPD exacerbation in the next year } \\
(\mathrm{N}=34,007), \mathrm{n}(\%)\end{array}$ & $P$ value \\
\hline $\begin{array}{l}\text { ICS, LABA, and LAMA combi- } \\
\text { nation }\end{array}$ & $16(0.04)$ & $0(0)$ & $16(0.05)$ & .66 \\
\hline Phosphodiesterase-4 inhibitor & $94(0.26)$ & $10(0.49)$ & $84(0.25)$ & .06 \\
\hline Systemic corticosteroid & $11,293(31.33)$ & $1144(56.08)$ & $10,149(29.84)$ & $<.001$ \\
\hline \multicolumn{5}{|l|}{ Comorbidity } \\
\hline Allergic rhinitis & $2445(6.78)$ & $174(8.53)$ & $2271(6.68)$ & .001 \\
\hline Anxiety or depression & $10,786(29.92)$ & $725(35.54)$ & $10,061(29.59)$ & $<.001$ \\
\hline Asthma & $4794(13.3)$ & $417(20.44)$ & $4377(12.87)$ & $<.001$ \\
\hline Congestive heart failure & $6063(16.82)$ & $495(24.26)$ & $5568(16.37)$ & $<.001$ \\
\hline Diabetes & $7623(21.15)$ & $446(21.86)$ & $7177(21.1)$ & .43 \\
\hline Eczema & $1558(4.32)$ & $98(4.8)$ & $1460(4.29)$ & .30 \\
\hline Gastroesophageal reflux & $7162(19.87)$ & $507(24.85)$ & $6655(19.57)$ & $<.001$ \\
\hline Hypertension & $18,361(50.94)$ & $1150(56.37)$ & $17,211(50.61)$ & $<.001$ \\
\hline Ischemic heart disease & $7420(20.58)$ & $486(23.82)$ & $6934(20.39)$ & $<.001$ \\
\hline Lung cancer & $794(2.2)$ & $52(2.55)$ & $742(2.18)$ & .31 \\
\hline Obesity & $3487(9.67)$ & $255(12.5)$ & $3232(9.5)$ & $<.001$ \\
\hline Sinusitis & $1382(3.83)$ & $83(4.07)$ & $1299(3.82)$ & .61 \\
\hline Sleep apnea & 3179 (8.82) & $253(12.4)$ & $2926(8.6)$ & $<.001$ \\
\hline
\end{tabular}

${ }^{\mathrm{a}} \mathrm{COPD}$ : chronic obstructive pulmonary disease.

${ }^{\mathrm{b}} P$ value $<.05$ is italicized and signifies a statistically significant difference in the patient characteristic distributions.

${ }^{\mathrm{c}}$ ICS: inhaled corticosteroid.

${ }^{\mathrm{d}}$ SAMA: short-acting muscarinic antagonist.

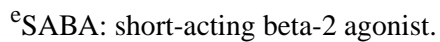

${ }^{\mathrm{L}} \mathrm{LAMA}$ : long-acting muscarinic antagonist.

${ }^{g}$ LABA: long-acting beta-2 agonist. 
Table 4. The patient characteristics of the data instances in the test set of the main analysis.

\begin{tabular}{|c|c|c|c|c|}
\hline Patient characteristic & $\begin{array}{l}\text { Data instances } \\
(\mathrm{N}=7529), \mathrm{n}(\%)\end{array}$ & $\begin{array}{l}\text { Data instances linked to severe COPD } \\
\text { exacerbations in the next year }(\mathrm{N}=182) \text {, } \\
\mathrm{n}(\%)\end{array}$ & $\begin{array}{l}\text { Data instances linked to no severe } \\
\text { COPD exacerbation in the next year } \\
(\mathrm{N}=7347), \mathrm{n}(\%)\end{array}$ & $P$ value \\
\hline Age (years) & & & & $<.001^{\mathrm{b}}$ \\
\hline $40-65$ & $3442(45.72)$ & $118(64.8)$ & $3324(45.24)$ & $<.001$ \\
\hline$>65$ & $4087(54.28)$ & $64(35.2)$ & $4023(54.76)$ & $<.001$ \\
\hline Sex & & & & $<.001$ \\
\hline Female & $3289(43.68)$ & $47(25.8)$ & $3242(44.13)$ & $<.001$ \\
\hline Male & $4240(56.32)$ & $135(74.2)$ & $4105(55.87)$ & $<.001$ \\
\hline Race & & & & $<.001$ \\
\hline $\begin{array}{l}\text { American Indian or Alaska } \\
\text { Native }\end{array}$ & $156(2.07)$ & $5(2.7)$ & $151(2.06)$ & $<.001$ \\
\hline Asian & $439(5.83)$ & $7(3.9)$ & $432(5.88)$ & $<.001$ \\
\hline Black or African American & $896(11.9)$ & $57(31.3)$ & $839(11.42)$ & $<.001$ \\
\hline $\begin{array}{l}\text { Native Hawaiian or other } \\
\text { Pacific Islander }\end{array}$ & $53(0.71)$ & $2(1.1)$ & $51(0.69)$ & $<.001$ \\
\hline White & $5793(76.94)$ & $111(61)$ & $5682(77.34)$ & $<.001$ \\
\hline $\begin{array}{l}\text { Other, unknown, or not re- } \\
\text { ported }\end{array}$ & $192(2.55)$ & $0(0)$ & $192(2.61)$ & $<.001$ \\
\hline Ethnicity & & & & .03 \\
\hline Hispanic & $188(2.5)$ & $3(1.6)$ & $185(2.52)$ & .03 \\
\hline Non-Hispanic & $7088(94.14)$ & $179(98.4)$ & $6909(94.04)$ & .03 \\
\hline Unknown or not reported & $253(3.36)$ & $0(0)$ & $253(3.44)$ & .03 \\
\hline Smoking status & & & & .03 \\
\hline Current smoker & $3893(51.71)$ & $112(61.5)$ & $3781(51.46)$ & .03 \\
\hline Former smoker & $1267(16.83)$ & $25(13.7)$ & $1242(16.91)$ & .03 \\
\hline Never smoker or unknown & $2369(31.47)$ & $45(24.7)$ & $2324(31.63)$ & .03 \\
\hline \multicolumn{5}{|l|}{ Insurance } \\
\hline Private & $4642(61.65)$ & $110(60.4)$ & $4532(61.69)$ & .79 \\
\hline Public & $6901(91.66)$ & $179(98.4)$ & $6722(91.49)$ & .002 \\
\hline Self-paid or charity & $540(7.17)$ & $41(22.5)$ & 499 (6.79) & $<.001$ \\
\hline \multicolumn{4}{|c|}{ Number of years from the first encounter related to COPD in the data set } & $<.001$ \\
\hline$\leq 3$ & $5154(68.46)$ & $81(44.5)$ & $5073(69.05)$ & $<.001$ \\
\hline$>3$ & $2375(31.54)$ & $101(55.5)$ & $2274(30.95)$ & $<.001$ \\
\hline \multicolumn{5}{|l|}{ COPD medication prescription } \\
\hline $\mathrm{ICS}^{\mathrm{c}}$ & $2635(35)$ & $98(53.8)$ & $2537(34.53)$ & $<.001$ \\
\hline SAMA $^{\mathrm{d}}$ & $1202(15.96)$ & $68(37.4)$ & $1134(15.43)$ & $<.001$ \\
\hline $\mathrm{SABA}^{\mathrm{e}}$ & $4241(56.33)$ & $158(86.8)$ & $4083(55.57)$ & $<.001$ \\
\hline $\begin{array}{l}\text { SABA and SAMA combina- } \\
\text { tion }\end{array}$ & $1809(24.03)$ & $115(63.2)$ & $1694(23.06)$ & $<.001$ \\
\hline LAMA $^{\mathrm{f}}$ & $2061(27.37)$ & $110(60.4)$ & $1951(26.56)$ & $<.001$ \\
\hline $\mathrm{LABA}^{\mathrm{g}}$ & $1760(23.38)$ & $77(42.3)$ & $1683(22.91)$ & $<.001$ \\
\hline $\begin{array}{l}\text { LABA and LAMA combina- } \\
\text { tion }\end{array}$ & $400(5.31)$ & $12(6.6)$ & $388(5.28)$ & .54 \\
\hline
\end{tabular}




\begin{tabular}{|c|c|c|c|c|}
\hline Patient characteristic & $\begin{array}{l}\text { Data instances } \\
(\mathrm{N}=7529), \mathrm{n}(\%)\end{array}$ & $\begin{array}{l}\text { Data instances linked to severe } \mathrm{COPD}^{\mathrm{a}} \\
\text { exacerbations in the next year }(\mathrm{N}=182) \text {, } \\
\mathrm{n}(\%)\end{array}$ & $\begin{array}{l}\text { Data instances linked to no severe } \\
\text { COPD exacerbation in the next year } \\
(\mathrm{N}=7347), \mathrm{n}(\%)\end{array}$ & $P$ value \\
\hline ICS and LABA combination & $1804(23.96)$ & $75(41.2)$ & $1729(23.53)$ & $<.001$ \\
\hline $\begin{array}{l}\text { ICS, LABA, and LAMA } \\
\text { combination }\end{array}$ & $69(0.92)$ & $1(0.5)$ & $68(0.93)$ & .90 \\
\hline $\begin{array}{l}\text { Phosphodiesterase-4 in- } \\
\text { hibitor }\end{array}$ & $26(0.35)$ & $2(1.1)$ & $24(0.33)$ & .27 \\
\hline Systemic corticosteroid & $2385(31.68)$ & $103(56.6)$ & $2282(31.06)$ & $<.001$ \\
\hline \multicolumn{5}{|l|}{ Comorbidity } \\
\hline Allergic rhinitis & $410(5.45)$ & $14(7.7)$ & $396(5.39)$ & .24 \\
\hline Anxiety or depression & $2153(28.6)$ & $63(34.6)$ & $2090(28.45)$ & .08 \\
\hline Asthma & $1096(14.56)$ & $43(23.6)$ & $1053(14.33)$ & $<.001$ \\
\hline Congestive heart failure & $1412(18.75)$ & $43(23.6)$ & $1369(18.63)$ & .11 \\
\hline Diabetes & $1689(22.43)$ & $40(22)$ & $1649(22.44)$ & .95 \\
\hline Eczema & $258(3.43)$ & $11(6)$ & $247(3.36)$ & .08 \\
\hline Gastroesophageal reflux & $1443(19.17)$ & $47(25.8)$ & $1396(19)$ & .03 \\
\hline Hypertension & $3791(50.35)$ & $105(57.7)$ & $3686(50.17)$ & .05 \\
\hline Ischemic heart disease & $1658(22.02)$ & $54(29.7)$ & $1604(21.83)$ & .02 \\
\hline Lung cancer & $203(2.7)$ & $3(1.6)$ & $200(2.72)$ & .51 \\
\hline Obesity & $669(8.89)$ & $21(11.5)$ & $648(8.82)$ & .25 \\
\hline Sinusitis & $279(3.71)$ & $7(3.8)$ & $272(3.7)$ & .99 \\
\hline Sleep apnea & 915 (12.15) & $28(15.4)$ & 887 (12.07) & .22 \\
\hline
\end{tabular}

${ }^{\mathrm{a} C O P D}$ : chronic obstructive pulmonary disease.

${ }^{\mathrm{b}} P$ value $<.05$ is italicized and signifies a statistically significant difference in the patient characteristic distributions.

${ }^{c}$ ICS: inhaled corticosteroid.

${ }^{\mathrm{d}}$ SAMA: short-acting muscarinic antagonist.

eSABA: short-acting beta-2 agonist.

LAMA: long-acting muscarinic antagonist.

${ }^{\mathrm{g}}$ LABA: long-acting beta-2 agonist.

\section{Classification Algorithm and Features Used in the Final Model}

The XGBoost algorithm was chosen by our automatic machine learning model selection method [89]. As a tree-based algorithm, XGBoost handles missing values in the features naturally. As detailed in Hastie et al [94], XGBoost automatically calculates an importance value for each feature based on the feature's apportioned contribution to the model. In the main analysis, the final model was created using XGBoost and the 229 features shown in descending order of their importance values in Table S2 of Multimedia Appendix 1. The other features contributed no extra predictive power and were automatically dropped by XGBoost.

\section{Model Performance in the Main Analysis}

In the main analysis with the test set, the final model had an AUC of 0.866 (95\% CI 0.838-0.892), as computed from the model's receiver operating characteristic curve (Figure 2). The model's performance measures varied with the cutoff threshold for binary classification (Table 5). When using the top $9.99 \%$
(752/7529) of the patients with the largest predicted risk to set the cutoff threshold for binary classification, the model had an accuracy of $90.33 \%$ (6801/7529; 95\% CI 89.61\%-91.01\%), a sensitivity of $56.6 \%(103 / 182 ; 95 \%$ CI $49.2 \%-64.2 \%)$, a specificity of $91.17 \%(6698 / 7347 ; 95 \%$ CI $90.51 \%-91.83 \%)$, a PPV of $13.7 \%$ (103/752; 95\% CI $11.2 \%-16.2 \%)$, and an NPV of $98.83 \%$ (6698/6777; 95\% CI 98.55\%-99.08\%), as computed from the corresponding confusion matrix of the model (Table $6)$.

Recall that 27 candidate features were computed on $\geq 2$ years of data. When we ignored these features and considered only those computed with the data in the index year, the model's AUC dropped from 0.866 to 0.859 (95\% CI 0.834-0.884). The top 19 features shown in Table S2 of Multimedia Appendix 1 have importance values $\geq 1 \%$. When using only these features, the model's AUC dropped from 0.866 to 0.862 (95\% CI $0.837-0.887)$. In this case, when using the top $9.99 \%$ (752/7529) of the patients with the largest predicted risk to set the cutoff threshold for binary classification, the model had an accuracy of $90.25 \%(6795 / 7529 ; 95 \%$ CI $89.56 \%-90.9 \%)$, a sensitivity of $54.9 \%(100 / 182 ; 95 \%$ CI $47.8 \%-61.9 \%)$, a specificity of 
$91.13 \%(6695 / 7347 ; 95 \%$ CI $90.43 \%-91.78 \%)$, a PPV of $13.3 \% \quad(6695 / 6777 ; 95 \%$ CI $98.52 \%-99.06 \%)$. $(100 / 752 ; 95 \%$ CI $10.9 \%-15.7 \%)$, and an NPV of 98.79

Figure 2. The receiver operating characteristic curve of the final model in the main analysis.

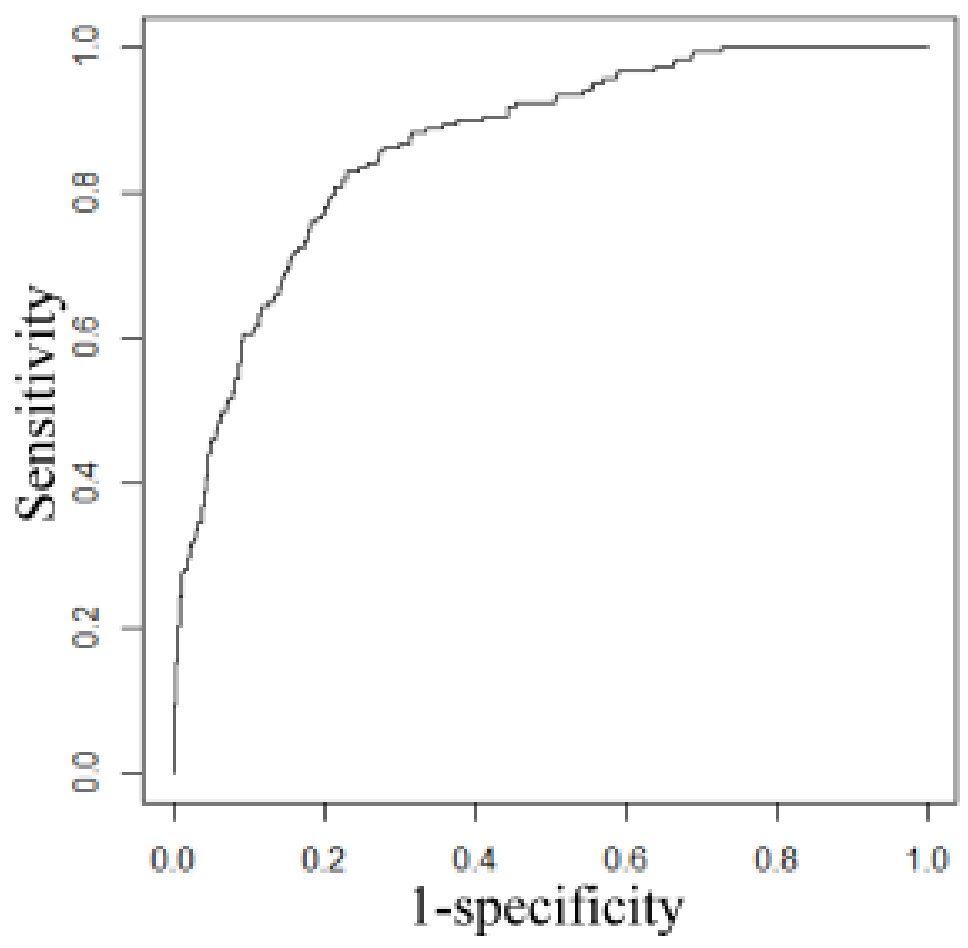

Table 5. In the main analysis, the performance measures of the final model with respect to using varying cutoff thresholds for binary classification.

\begin{tabular}{|c|c|c|c|c|c|c|c|}
\hline \multirow{2}{*}{$\begin{array}{l}\text { Top percentage of patients with } \\
\text { the largest predicted risk }(\%)\end{array}$} & \multirow{2}{*}{$\begin{array}{l}\text { Accuracy } \\
(\mathrm{N}=7529), \mathrm{n}(\%)\end{array}$} & \multirow{2}{*}{$\begin{array}{l}\text { Sensitivity } \\
(\mathrm{N}=182), \mathrm{n}(\%)\end{array}$} & \multirow{2}{*}{$\begin{array}{l}\text { Specificity } \\
(\mathrm{N}=7347), \mathrm{n}(\%)\end{array}$} & \multicolumn{2}{|c|}{ Positive predictive value } & \multicolumn{2}{|c|}{ Negative predictive value } \\
\hline & & & & $\mathrm{n}(\%)$ & $\mathrm{N}$ & $\mathrm{n}(\%)$ & $\mathrm{N}$ \\
\hline 1 & $7336(97.4)$ & $32(17.6)$ & 7304 (99.4) & $32(42.7)$ & 75 & $7304(98)$ & 7454 \\
\hline 2 & $7299(96.9)$ & $51(28)$ & $7248(98.7)$ & $51(34)$ & 150 & $7248(98.2)$ & 7379 \\
\hline 3 & $7236(96.1)$ & $57(31.3)$ & 7179 (97.7) & $57(25.3)$ & 225 & $7179(98.3)$ & 7304 \\
\hline 4 & $7170(95.2)$ & $62(34.1)$ & $7108(96.7)$ & $62(20.6)$ & 301 & $7108(98.3)$ & 7228 \\
\hline 5 & $7111(94.4)$ & $70(38.5)$ & $7041(95.8)$ & $70(18.6)$ & 376 & $7041(98.4)$ & 7153 \\
\hline 6 & $7062(93.8)$ & $83(45.6)$ & $6979(95)$ & $83(18.4)$ & 451 & 6979 (98.6) & 7078 \\
\hline 7 & $6994(92.9)$ & $87(47.8)$ & $6907(94)$ & $87(16.5)$ & 527 & 6907 (98.6) & 7002 \\
\hline 8 & $6927(92)$ & $91(50)$ & $6836(93)$ & $91(15.1)$ & 602 & $6836(98.7)$ & 6927 \\
\hline 9 & $6860(91.1)$ & $95(52.2)$ & $6765(92.1)$ & $95(14)$ & 677 & 6765 (98.7) & 6852 \\
\hline 10 & $6801(90.3)$ & $103(56.6)$ & $6698(91.2)$ & 103 (13.7) & 752 & 6698 (98.8) & 6777 \\
\hline 15 & $6458(85.8)$ & $120(65.9)$ & $6338(86.3)$ & $120(10.6)$ & 1129 & 6338 (99) & 6400 \\
\hline 20 & $6118(81.3)$ & $138(75.8)$ & $5980(81.4)$ & $138(9.2)$ & 1505 & $5980(99.3)$ & 6024 \\
\hline 25 & 5767 (76.6) & $151(83)$ & $5616(76.4)$ & $151(8)$ & 1882 & 5616 (99.5) & 5647 \\
\hline
\end{tabular}


Table 6. The confusion matrix of the final model in the main analysis when using the top $9.99 \%$ (794/7944) of the patients with the largest predicted risk to set the cutoff threshold for binary classification.

\begin{tabular}{lll}
\hline Outcome class & Severe COPD ${ }^{\mathrm{a}}$ exacerbations in the next year & No severe COPD exacerbation in the next year \\
\hline $\begin{array}{l}\text { Predicted severe COPD exacerbations in the next year } \\
\text { Predicted no severe COPD exacerbation in the next }\end{array}$ & 79 & 649 \\
year & & 6698 \\
\hline
\end{tabular}

${ }^{\mathrm{a} C O P D}$ : chronic obstructive pulmonary disease.

\section{Performance Stability Analysis}

The final model in the main analysis and the model in the performance stability analysis had relatively similar performance (Table 7).

Table 7. The performance of the final model in the main analysis and the model in the performance stability analysis.

\begin{tabular}{lllll}
\hline Performance measure & \multicolumn{2}{l}{$\begin{array}{l}\text { Final model in the main analysis } \\
\mathrm{n}(\% ; 95 \% \mathrm{CI})\end{array}$} & $\mathrm{N}$ & $\mathrm{l}$ Model in the performance stability analysis ${ }^{\mathrm{b}}$ \\
\hline Accuracy & $6801(90.3 ; 89.6-91.0)$ & 7529 & $6354(89.6 ; 88.9-90.3)$ & $\mathrm{N}$ \\
Sensitivity & $103(56.6 ; 49.2-64.2)$ & 182 & $171(46.3 ; 40.9-51.5)$ & 3089 \\
Specificity & $6698(91.2 ; 90.5-91.8)$ & 7347 & $6183(92 ; 91.4-92.7)$ & 6720 \\
Positive predictive value & $103(13.7 ; 11.2-16.2)$ & 752 & $171(24.2 ; 20.8-27.2)$ & 708 \\
Negative predictive value & $6698(98.8 ; 98.6-99.1)$ & 6777 & $6183(96.9 ; 96.4-97.3)$ & 6381 \\
\hline
\end{tabular}

${ }^{\mathrm{a}}$ Area under the receiver operating characteristic curve of 0.866 (95\% CI 0.838-0.892).

${ }^{\mathrm{b}}$ Area under the receiver operating characteristic curve of 0.847 (95\% CI 0.828-0.864).

\section{Discussion}

\section{Principal Findings}

We created a machine learning model to predict severe COPD exacerbations in the next year in patients with COPD. The model had a higher AUC than the formerly published AUC of every prior model for predicting severe COPD exacerbations in the next year [20,25,27,28,30,33,35-43,46-49,51] (Tables 8 and 9). After improving our model's performance measures further (eg, by adding features extracted from clinical notes) and using our recently published automatic explanation method [95] to automatically explain the model's predictions, our model could be used as a decision support tool to advise the use of care management for patients with COPD and at high risk to improve outcomes.
In Table S2 of Multimedia Appendix 1, many of the top 19 features match the published (risk) factors that were highly correlated with COPD exacerbations, such as prior COPD exacerbations $[18,60]$, prior health care encounters related to COPD [28,50], COPD medication use [50], BMI [70], peripheral capillary oxygen saturation [28], and heart rate [71].

We examined 278 candidate features, 82.4\% (229/278) of which were used in the final model. Many omitted features are correlated with the outcome, but they provided no extra predictive power on the UWM data set beyond the 229 features used in the final model.

The prevalence rate of severe COPD exacerbations had a sudden drop in 2019. Despite this drop, our model still showed reasonably robust performance over time. This is desired for clinical decision support. 
Table 8. A comparison of our final model and several prior models to predict severe chronic obstructive pulmonary disease (COPD) exacerbations in patients with COPD (Part 1).

\begin{tabular}{|c|c|c|c|c|c|c|c|c|c|c|c|c|}
\hline Model & Data & $\begin{array}{l}\text { Number } \\
\text { of data in- } \\
\text { stances }\end{array}$ & $\begin{array}{l}\text { Prediction tar- } \\
\text { get (outcome) }\end{array}$ & $\begin{array}{l}\text { Length of } \\
\text { the period } \\
\text { used to } \\
\text { compute } \\
\text { the out- } \\
\text { come }\end{array}$ & $\begin{array}{l}\text { Preva- } \\
\text { lence rate } \\
\text { of the } \\
\text { poor out- } \\
\text { come }(\%)\end{array}$ & $\begin{array}{l}\text { Number } \\
\text { of fea- } \\
\text { tures } \\
\text { checked }\end{array}$ & $\begin{array}{l}\text { Classifica- } \\
\text { tion algo- } \\
\text { rithm }\end{array}$ & $\begin{array}{l}\text { Sensitiv- } \\
\text { ity }(\%)\end{array}$ & $\begin{array}{l}\text { Speci- } \\
\text { ficity } \\
(\%)\end{array}$ & $\begin{array}{l}\mathrm{PPV}^{\mathrm{a}} \\
(\%)\end{array}$ & $\begin{array}{l}\mathrm{NPV}^{\mathrm{b}} \\
(\%)\end{array}$ & $\mathrm{AUC}^{\mathrm{C}}$ \\
\hline $\begin{array}{l}\text { Our final } \\
\text { model }\end{array}$ & $\begin{array}{l}\text { Adminis- } \\
\text { trative } \\
\text { and clini- } \\
\text { cal }\end{array}$ & 43,576 & $\begin{array}{l}\mathrm{ED}^{\mathrm{d}} \text { visit or in- } \\
\text { patient stay for } \\
\text { COPD }\end{array}$ & 1 year & 5.1 & 278 & $\begin{array}{l}\text { XG- } \\
\text { Boost }^{\mathrm{e}}\end{array}$ & 56.6 & 91.17 & 13.7 & 98.83 & 0.866 \\
\hline $\begin{array}{l}\text { Annavara- } \\
\text { pu et al } \\
{[20]}\end{array}$ & $\begin{array}{l}\text { Adminis- } \\
\text { trative }\end{array}$ & 45,722 & $\begin{array}{l}\text { Inpatient stay } \\
\text { for COPD }\end{array}$ & 1 year & 11.63 & 103 & $\begin{array}{l}\text { Logistic } \\
\text { regres- } \\
\text { sion }\end{array}$ & 17.3 & 97.5 & 48.1 & 90 & 0.77 \\
\hline $\begin{array}{l}\text { Tavakoli } \\
\text { et al [21] }\end{array}$ & $\begin{array}{l}\text { Adminis- } \\
\text { trative }\end{array}$ & 222,219 & $\begin{array}{l}\text { Inpatient stay } \\
\text { for COPD }\end{array}$ & 2 months & 1.02 & 83 & $\begin{array}{l}\text { Gradient } \\
\text { boosting }\end{array}$ & 23 & 98 & $-^{f}$ & - & 0.820 \\
\hline $\begin{array}{l}\text { Samp et } \\
\text { al [22] }\end{array}$ & $\begin{array}{l}\text { Adminis- } \\
\text { trative }\end{array}$ & 478,772 & $\begin{array}{l}\text { Inpatient stay } \\
\text { for COPD }\end{array}$ & 6 months & 2.2 & 101 & $\begin{array}{l}\text { Logistic } \\
\text { regres- } \\
\text { sion }\end{array}$ & 17.6 & 96.6 & - & - & - \\
\hline $\begin{array}{l}\text { Thomsen } \\
\text { et al [23] }\end{array}$ & Research & 6574 & $\begin{array}{l}\text { Two or more } \\
\text { exacerbations } \\
\text { (medication } \\
\text { change or inpa- } \\
\text { tient stay for } \\
\text { COPD) }\end{array}$ & $1-7$ years & 6.4 & 11 & $\begin{array}{l}\text { Logistic } \\
\text { regres- } \\
\text { sion }\end{array}$ & - & - & 18 & 96 & 0.73 \\
\hline $\begin{array}{l}\text { Orchard } \\
\text { et al [24] }\end{array}$ & Research & 57,150 & $\begin{array}{l}\text { Inpatient stay } \\
\text { for COPD }\end{array}$ & 1 day & 0.1 & 153 & $\begin{array}{l}\text { Neural } \\
\text { network }\end{array}$ & 80 & 60 & - & - & 0.740 \\
\hline $\begin{array}{l}\text { Suetomo } \\
\text { et al [25] }\end{array}$ & Research & 123 & $\begin{array}{l}\text { Inpatient stay } \\
\text { for COPD }\end{array}$ & 1 year & 12.2 & 18 & $\begin{array}{l}\text { Logistic } \\
\text { regres- } \\
\text { sion }\end{array}$ & 53 & 49 & - & - & 0.79 \\
\hline $\begin{array}{l}\text { Lee et al } \\
{[26]}\end{array}$ & $\begin{array}{l}\text { Research } \\
\text { and clini- } \\
\text { cal }\end{array}$ & 545 & $\begin{array}{l}\text { Medication } \\
\text { change, ED vis- } \\
\text { it, or inpatient } \\
\text { stay for COPD }\end{array}$ & 6 months & 46 & 10 & $\begin{array}{l}\text { Logistic } \\
\text { regres- } \\
\text { sion }\end{array}$ & 52 & 69 & - & - & 0.63 \\
\hline $\begin{array}{l}\text { Faganello } \\
\text { et al [27] }\end{array}$ & Research & 120 & $\begin{array}{l}\text { Outpatient, inpa- } \\
\text { tient, or ED en- } \\
\text { counter for } \\
\text { COPD }\end{array}$ & 1 year & 50 & 16 & $\begin{array}{l}\text { Logistic } \\
\text { regres- } \\
\text { sion }\end{array}$ & 58.3 & 73.3 & - & - & 0.686 \\
\hline $\begin{array}{l}\text { Alcázar } \\
\text { et al [28] }\end{array}$ & Research & 127 & $\begin{array}{l}\text { Inpatient stay } \\
\text { for COPD }\end{array}$ & 1 year & 39.4 & 9 & $\begin{array}{l}\text { Logistic } \\
\text { regres- } \\
\text { sion }\end{array}$ & 76.2 & 77.3 & 61.5 & 87.2 & 0.809 \\
\hline $\begin{array}{l}\text { Bertens et } \\
\text { al [29] }\end{array}$ & $\begin{array}{l}\text { Research } \\
\text { and clini- } \\
\text { cal }\end{array}$ & 1033 & $\begin{array}{l}\text { Medication } \\
\text { change or inpa- } \\
\text { tient stay for } \\
\text { COPD }\end{array}$ & 2 years & 28.3 & 7 & $\begin{array}{l}\text { Logistic } \\
\text { regres- } \\
\text { sion }\end{array}$ & - & - & - & - & 0.66 \\
\hline $\begin{array}{l}\text { Mirav- } \\
\text { itlles et al } \\
{[30]}\end{array}$ & $\begin{array}{l}\text { Research } \\
\text { and clini- } \\
\text { cal }\end{array}$ & 713 & $\begin{array}{l}\text { Inpatient stay } \\
\text { for COPD }\end{array}$ & 1 year & 22.2 & 7 & $\begin{array}{l}\text { Logistic } \\
\text { regres- } \\
\text { sion }\end{array}$ & - & - & - & - & 0.582 \\
\hline $\begin{array}{l}\text { Make et } \\
\text { al [31] }\end{array}$ & Research & 3141 & $\begin{array}{l}\text { Medication } \\
\text { change, ED vis- } \\
\text { it, or inpatient } \\
\text { stay for COPD }\end{array}$ & 6 months & - & 38 & $\begin{array}{l}\text { Logistic } \\
\text { regres- } \\
\text { sion }\end{array}$ & - & - & - & - & 0.67 \\
\hline $\begin{array}{l}\text { Montser- } \\
\text { rat- } \\
\text { Capdev- } \\
\text { ila et al } \\
{[32]}\end{array}$ & $\begin{array}{l}\text { Adminis- } \\
\text { trative } \\
\text { and clini- } \\
\text { cal }\end{array}$ & 2501 & $\begin{array}{l}\text { Inpatient stay } \\
\text { for COPD }\end{array}$ & 3 years & 32.5 & 17 & $\begin{array}{l}\text { Logistic } \\
\text { regres- } \\
\text { sion }\end{array}$ & - & - & - & - & 0.72 \\
\hline
\end{tabular}




\begin{tabular}{|c|c|c|c|c|c|c|c|c|c|c|c|c|}
\hline Model & Data & $\begin{array}{l}\text { Number } \\
\text { of data in- } \\
\text { stances }\end{array}$ & $\begin{array}{l}\text { Prediction tar- } \\
\text { get (outcome) }\end{array}$ & $\begin{array}{l}\text { Length of } \\
\text { the period } \\
\text { used to } \\
\text { compute } \\
\text { the out- } \\
\text { come }\end{array}$ & $\begin{array}{l}\text { Preva- } \\
\text { lence rate } \\
\text { of the } \\
\text { poor out- } \\
\text { come }(\%)\end{array}$ & $\begin{array}{l}\text { Number } \\
\text { of fea- } \\
\text { tures } \\
\text { checked }\end{array}$ & $\begin{array}{l}\text { Classifica- } \\
\text { tion algo- } \\
\text { rithm }\end{array}$ & $\begin{array}{l}\text { Sensitiv- } \\
\text { ity }(\%)\end{array}$ & $\begin{array}{l}\text { Speci- } \\
\text { ficity } \\
(\%)\end{array}$ & $\begin{array}{l}\mathrm{PPV}^{\mathrm{a}} \\
(\%)\end{array}$ & $\begin{array}{l}\mathrm{NPV}^{\mathrm{b}} \\
(\%)\end{array}$ & $\mathrm{AUC}^{\mathrm{c}}$ \\
\hline $\begin{array}{l}\text { Kerkhof } \\
\text { et al [33] }\end{array}$ & $\begin{array}{l}\text { Research } \\
\text { and clini- } \\
\text { cal }\end{array}$ & 16,565 & $\begin{array}{l}\text { Two or more } \\
\text { exacerbations } \\
\text { (medication } \\
\text { change, ED vis- } \\
\text { it, or inpatient } \\
\text { stay for COPD) }\end{array}$ & 1 year & 19.6 & 22 & $\begin{array}{l}\text { Logistic } \\
\text { regres- } \\
\text { sion }\end{array}$ & - & - & - & - & 0.735 \\
\hline $\begin{array}{l}\text { Chen et } \\
\text { al [34] }\end{array}$ & Research & 1711 & $\begin{array}{l}\text { ED visit or inpa- } \\
\text { tient stay for } \\
\text { COPD }\end{array}$ & 5 years & 30.6 & 14 & $\begin{array}{l}\text { Cox pro- } \\
\text { portional } \\
\text { hazard re- } \\
\text { gression }\end{array}$ & - & - & - & - & 0.74 \\
\hline $\begin{array}{l}\text { Yii et al } \\
{[35]}\end{array}$ & $\begin{array}{l}\text { Adminis- } \\
\text { trative } \\
\text { and clini- } \\
\text { cal }\end{array}$ & 237 & $\begin{array}{l}\text { Inpatient stay } \\
\text { for COPD }\end{array}$ & 1 year & $\begin{array}{l}1.41 \text { per } \\
\text { patient } \\
\text { year }\end{array}$ & 31 & $\begin{array}{l}\text { Negative } \\
\text { binomial } \\
\text { regres- } \\
\text { sion }\end{array}$ & - & - & - & - & 0.789 \\
\hline
\end{tabular}

${ }^{\mathrm{a} P P V}$ : positive predictive value.

${ }^{\mathrm{b}} \mathrm{NPV}$ : negative predictive value.

${ }^{\mathrm{c}}$ AUC: area under the receiver operating characteristic curve.

${ }^{\mathrm{d}}$ ED: emergency department.

${ }^{\mathrm{e}}$ XGBoost: Extreme Gradient Boosting.

${ }^{\mathrm{f}}$ The performance measure is unreported in the initial paper describing the model. 
Table 9. A comparison of our final model and several prior models to predict severe chronic obstructive pulmonary disease (COPD) exacerbations in patients with COPD (Part 2)

\begin{tabular}{|c|c|c|c|c|c|c|c|c|c|c|c|c|}
\hline Model & Data & $\begin{array}{l}\text { Number } \\
\text { of data in- } \\
\text { stances }\end{array}$ & $\begin{array}{l}\text { Prediction tar- } \\
\text { get (outcome) }\end{array}$ & $\begin{array}{l}\text { Length of } \\
\text { the period } \\
\text { used to } \\
\text { compute } \\
\text { the out- } \\
\text { come }\end{array}$ & $\begin{array}{l}\text { Preva- } \\
\text { lence rate } \\
\text { of the } \\
\text { poor out- } \\
\text { come }(\%)\end{array}$ & $\begin{array}{l}\text { Number } \\
\text { of fea- } \\
\text { tures } \\
\text { checked }\end{array}$ & $\begin{array}{l}\text { Classifica- } \\
\text { tion algo- } \\
\text { rithm }\end{array}$ & $\begin{array}{l}\text { Sensitiv- } \\
\text { ity }(\%)\end{array}$ & $\begin{array}{l}\text { Speci- } \\
\text { ficity } \\
(\%)\end{array}$ & $\begin{array}{l}\mathrm{PPV}^{\mathrm{a}} \\
(\%)\end{array}$ & $\begin{array}{l}\mathrm{NPV}^{\mathrm{b}} \\
(\%)\end{array}$ & $\mathrm{AUC}^{\mathrm{C}}$ \\
\hline $\begin{array}{l}\text { Our final } \\
\text { model }\end{array}$ & $\begin{array}{l}\text { Adminis- } \\
\text { trative } \\
\text { and clini- } \\
\text { cal }\end{array}$ & 43,576 & $\begin{array}{l}\mathrm{ED}^{\mathrm{d}} \text { visit or in- } \\
\text { patient stay for } \\
\text { COPD }\end{array}$ & 1 year & 5.1 & 278 & $\begin{array}{l}\text { XG- } \\
\text { Boost }^{e}\end{array}$ & 56.6 & 91.17 & 13.7 & 98.83 & 0.866 \\
\hline $\begin{array}{l}\text { Adibi et } \\
\text { al [36] }\end{array}$ & Research & 2380 & $\begin{array}{l}\text { ED visit or inpa- } \\
\text { tient stay for } \\
\text { COPD }\end{array}$ & 1 year & $\begin{array}{l}0.29 \text { per } \\
\text { year }\end{array}$ & 13 & $\begin{array}{l}\text { Mixed ef- } \\
\text { fect logis- } \\
\text { tic }\end{array}$ & $-^{f}$ & - & - & - & 0.77 \\
\hline $\begin{array}{l}\text { Stanford } \\
\text { et al [37] }\end{array}$ & $\begin{array}{l}\text { Adminis- } \\
\text { trative }\end{array}$ & 258,668 & $\begin{array}{l}\text { Inpatient stay } \\
\text { for COPD }\end{array}$ & 1 year & 8.5 & 30 & $\begin{array}{l}\text { Logistic } \\
\text { regres- } \\
\text { sion }\end{array}$ & - & - & - & - & 0.749 \\
\hline $\begin{array}{l}\text { Stanford } \\
\text { et al [38] }\end{array}$ & $\begin{array}{l}\text { Adminis- } \\
\text { trative }\end{array}$ & 223,824 & $\begin{array}{l}\text { Inpatient stay } \\
\text { for COPD }\end{array}$ & 1 year & 6.63 & 30 & $\begin{array}{l}\text { Logistic } \\
\text { regres- } \\
\text { sion }\end{array}$ & - & - & - & - & 0.711 \\
\hline $\begin{array}{l}\text { Stanford } \\
\text { et al [39] }\end{array}$ & $\begin{array}{l}\text { Adminis- } \\
\text { trative }\end{array}$ & 92,496 & $\begin{array}{l}\text { Inpatient stay } \\
\text { for COPD }\end{array}$ & 1 year & - & 30 & $\begin{array}{l}\text { Logistic } \\
\text { regres- } \\
\text { sion }\end{array}$ & - & - & - & - & 0.801 \\
\hline $\begin{array}{l}\text { Stanford } \\
\text { et al [40] }\end{array}$ & $\begin{array}{l}\text { Adminis- } \\
\text { trative }\end{array}$ & 60,776 & $\begin{array}{l}\text { Inpatient stay } \\
\text { for COPD }\end{array}$ & 1 year & 19.16 & 8 & $\begin{array}{l}\text { Logistic } \\
\text { regres- } \\
\text { sion }\end{array}$ & - & - & - & - & 0.742 \\
\hline $\begin{array}{l}\text { Jones et } \\
\text { al [41] }\end{array}$ & Clinical & 375 & $\begin{array}{l}\text { Inpatient stay } \\
\text { for COPD }\end{array}$ & 1 year & - & 4 & Index & - & - & - & - & 0.755 \\
\hline $\begin{array}{l}\text { Jones et } \\
\text { al [42] }\end{array}$ & $\begin{array}{l}\text { Research } \\
\text { and clini- } \\
\text { cal }\end{array}$ & 7105 & $\begin{array}{l}\text { Inpatient stay } \\
\text { for COPD }\end{array}$ & 1 year & - & 8 & $\begin{array}{l}\text { Negative } \\
\text { binomial } \\
\text { regres- } \\
\text { sion }\end{array}$ & - & - & - & - & 0.64 \\
\hline $\begin{array}{l}\text { Fan et al } \\
{[43]}\end{array}$ & Research & 3282 & $\begin{array}{l}\text { Inpatient stay } \\
\text { for COPD }\end{array}$ & 1 year & 4.3 & 23 & $\begin{array}{l}\text { Logistic } \\
\text { regres- } \\
\text { sion }\end{array}$ & - & - & - & - & 0.706 \\
\hline $\begin{array}{l}\text { Moy et al } \\
\text { [44] }\end{array}$ & $\begin{array}{l}\text { Research } \\
\text { and clini- } \\
\text { cal }\end{array}$ & 167 & $\begin{array}{l}\text { Inpatient stay } \\
\text { for COPD }\end{array}$ & $\begin{array}{l}4-21 \\
\text { months }\end{array}$ & 32.9 & 6 & $\begin{array}{l}\text { Negative } \\
\text { binomial } \\
\text { regres- } \\
\text { sion }\end{array}$ & - & - & - & - & 0.69 \\
\hline $\begin{array}{l}\text { Briggs et } \\
\text { al [45] }\end{array}$ & Research & 8802 & $\begin{array}{l}\text { Inpatient stay } \\
\text { for COPD }\end{array}$ & $\begin{array}{l}6 \text { months } \\
\text { to } 3 \text { years }\end{array}$ & 9 & 13 & $\begin{array}{l}\text { Cox pro- } \\
\text { portional } \\
\text { hazard re- } \\
\text { gression }\end{array}$ & - & - & - & - & 0.71 \\
\hline $\begin{array}{l}\text { Lange et } \\
\text { al [46] }\end{array}$ & $\begin{array}{l}\text { Adminis- } \\
\text { trative } \\
\text { and re- } \\
\text { search }\end{array}$ & 6628 & $\begin{array}{l}\text { Medication } \\
\text { change or inpa- } \\
\text { tient stay for } \\
\text { COPD }\end{array}$ & 1 year & 4.8 & 3 & $\begin{array}{l}\text { GOLD }^{\mathrm{g}} \\
\text { stratifica- } \\
\text { tion }\end{array}$ & - & - & - & - & 0.7 \\
\hline $\begin{array}{l}\text { Abascal- } \\
\text { Bolado et } \\
\text { al [47] }\end{array}$ & $\begin{array}{l}\text { Research } \\
\text { and clini- } \\
\text { cal }\end{array}$ & 493 & $\begin{array}{l}\text { Inpatient stay } \\
\text { for COPD }\end{array}$ & 1 year & - & 8 & $\begin{array}{l}\text { Classifica- } \\
\text { tion and } \\
\text { regres- } \\
\text { sion tree }\end{array}$ & - & - & - & - & 0.70 \\
\hline $\begin{array}{l}\text { Blanco- } \\
\text { Aparicio } \\
\text { et al [48] }\end{array}$ & Research & 100 & $\begin{array}{l}\text { ED visit for } \\
\text { COPD }\end{array}$ & 1 year & 21 & 12 & $\begin{array}{l}\text { Logistic } \\
\text { regres- } \\
\text { sion }\end{array}$ & - & - & - & - & 0.651 \\
\hline $\begin{array}{l}\text { Yoo et al } \\
\text { [49] }\end{array}$ & $\begin{array}{l}\text { Research } \\
\text { and clini- } \\
\text { cal }\end{array}$ & 260 & $\begin{array}{l}\text { Medication } \\
\text { change, ED vis- } \\
\text { it, or inpatient } \\
\text { stay for COPD }\end{array}$ & 1 year & 40.8 & 17 & $\begin{array}{l}\text { Logistic } \\
\text { regres- } \\
\text { sion }\end{array}$ & - & - & - & - & 0.69 \\
\hline
\end{tabular}




\begin{tabular}{|c|c|c|c|c|c|c|c|c|c|c|c|c|}
\hline Model & Data & $\begin{array}{l}\text { Number } \\
\text { of data in- } \\
\text { stances }\end{array}$ & $\begin{array}{l}\text { Prediction tar- } \\
\text { get (outcome) }\end{array}$ & $\begin{array}{l}\text { Length of } \\
\text { the period } \\
\text { used to } \\
\text { compute } \\
\text { the out- } \\
\text { come }\end{array}$ & $\begin{array}{l}\text { Preva- } \\
\text { lence rate } \\
\text { of the } \\
\text { poor out- } \\
\text { come }(\%)\end{array}$ & $\begin{array}{l}\text { Number } \\
\text { of fea- } \\
\text { tures } \\
\text { checked }\end{array}$ & $\begin{array}{l}\text { Classifica- } \\
\text { tion algo- } \\
\text { rithm }\end{array}$ & $\begin{array}{l}\text { Sensitiv- } \\
\text { ity }(\%)\end{array}$ & $\begin{array}{l}\text { Speci- } \\
\text { ficity } \\
(\%)\end{array}$ & $\begin{array}{l}\mathrm{PPV}^{\mathrm{a}} \\
(\%)\end{array}$ & $\begin{array}{l}\mathrm{NPV}^{\mathrm{b}} \\
(\%)\end{array}$ & $\mathrm{AUC}^{\mathrm{c}}$ \\
\hline $\begin{array}{l}\text { Niewoehn- } \\
\text { er et al } \\
{[50]}\end{array}$ & $\begin{array}{l}\text { Research } \\
\text { and clini- } \\
\text { cal }\end{array}$ & 1829 & $\begin{array}{l}\text { Inpatient stay } \\
\text { for COPD }\end{array}$ & 6 months & 8.3 & 27 & $\begin{array}{l}\text { Cox pro- } \\
\text { portional } \\
\text { hazard re- } \\
\text { gression }\end{array}$ & - & - & - & - & 0.73 \\
\hline $\begin{array}{l}\text { Austin et } \\
\text { al [51] }\end{array}$ & $\begin{array}{l}\text { Adminis- } \\
\text { trative }\end{array}$ & 638,926 & $\begin{array}{l}\text { COPD-related } \\
\text { inpatient stay }\end{array}$ & 1 year & - & 34 & $\begin{array}{l}\text { Logistic } \\
\text { regres- } \\
\text { sion }\end{array}$ & - & - & - & - & 0.778 \\
\hline $\begin{array}{l}\text { Marin et } \\
\text { al [52] }\end{array}$ & Research & 275 & $\begin{array}{l}\text { Inpatient stay } \\
\text { for COPD }\end{array}$ & $\begin{array}{l}6 \text { months } \\
\text { to } 8 \text { years }\end{array}$ & - & 4 & $\begin{array}{l}\text { Logistic } \\
\text { regres- } \\
\text { sion }\end{array}$ & 86 & 73 & - & - & 0.88 \\
\hline $\begin{array}{l}\text { Marin et } \\
\text { al [52] }\end{array}$ & Research & 275 & $\begin{array}{l}\text { ED visit for } \\
\text { COPD }\end{array}$ & $\begin{array}{l}6 \text { months } \\
\text { to } 8 \text { years }\end{array}$ & - & 4 & $\begin{array}{l}\text { Logistic } \\
\text { regres- } \\
\text { sion }\end{array}$ & 58 & 87 & - & - & 0.78 \\
\hline $\begin{array}{l}\text { Ställberg } \\
\text { et al [53] }\end{array}$ & $\begin{array}{l}\text { Adminis- } \\
\text { trative } \\
\text { and clini- } \\
\text { cal }\end{array}$ & 7823 & $\begin{array}{l}\text { COPD-related } \\
\text { inpatient stay }\end{array}$ & 10 days & - & $>4000$ & XGBoost & 16 & - & 11 & - & 0.86 \\
\hline
\end{tabular}

${ }^{\mathrm{a}} \mathrm{PPV}$ : positive predictive value.

${ }^{b} \mathrm{NPV}$ : negative predictive value.

${ }^{\mathrm{c}} \mathrm{AUC}$ : area under the receiver operating characteristic curve.

${ }^{\mathrm{d}} \mathrm{ED}$ : emergency department.

${ }^{\mathrm{e} X G B o o s t}$ : Extreme Gradient Boosting.

${ }^{\mathrm{f}}$ The performance measure is unreported in the initial paper describing the model.

${ }^{\mathrm{g}}$ GOLD: Global Initiative for Chronic Obstructive Lung Disease.

\section{Comparison With Prior Work}

Researchers formerly created several models to predict severe COPD exacerbations in patients with COPD [20-53]. Tables 8 and 9 present comparisons between our final model and these models, which include all related models listed in the systematic reviews by Guerra et al [96] and Bellou et al [97] as well as several recent models that were published after the reviews. Our final model predicted severe COPD exacerbations in the next year. Every prior model for predicting severe COPD exacerbations in the next year had an AUC $\leq 0.809$, that is, at least 0.057 lower than that of our final model. Compared with the prior models for predicting severe COPD exacerbations other than the model developed by Ställberg et al [53], our final model used more extensive features with predictive power, which helped improve model performance.

Our final model's prediction target covered both future ED visits and future inpatient stays for COPD, which we want to use care management to prevent. Among all prior models, only $2[34,36]$ had prediction targets covering both future ED visits and future inpatient stays for COPD. Most of the prior models predicted either only future ED visits [48,52] or only future inpatient stays for COPD [20-22,24,25,28,30,32,35,37-45, 47,50-52]. This would be insufficient for preventing both future ED visits and future inpatient stays for COPD. The other prior models [23,26,27,29,31,33,46,49] had prediction targets covering both moderate and severe COPD exacerbations, with moderate COPD exacerbations typically referring to COPD medication change such as the use of systemic corticosteroids. These prediction targets were not specific enough for identifying patients at the highest risk for care management because a care management program can host only a small portion of patients [17].

To make it suitable for use in daily clinical practice, our final model was built on routinely available administrative and clinical data. In comparison, the models developed by several other research groups [23-31,33,34,36,42-50,52] used research data, some of which are unavailable in usual clinical practice. Thus, these models would be unsuitable for daily clinical use.

Our predictive model was developed to guide COPD care management's enrollment decisions and to prevent severe COPD exacerbations. To give enough lead time for preventive interventions to be effective and to use precious care management resources well, we chose severe COPD exacerbation in the next year as the prediction target. In comparison, the model developed by Orchard et al [24] predicted inpatient stays for COPD on the next day. If a patient will incur an inpatient stay for COPD tomorrow, intervening starting from today could be too late to avoid the inpatient stay. At present, we are aware of no published conclusion on how long it will take for any intervention to be effective at preventing severe COPD exacerbations. In the studies by Longman et al [98] and Johnston et al [99], several clinicians had expressed the opinion that it could take as long as 3 months for any intervention to be 
effective at preventing inpatient stays for a chronic, ambulatory care-sensitive condition. Our final model will have a different clinical use from the models that make short-term predictions. Foreseeing a severe COPD exacerbation in the next 12 months would be useful for identifying and personalizing medium-term interventions and maintenance therapies to change the course of the disease. In comparison, foreseeing a severe COPD exacerbation in the next 1 or few days can be useful for deciding acute management approaches to improve outcomes, such as preemptive hospitalization of the patient to avoid more severe adverse outcomes, but would be inadequate for trying to improve the course of the disease in a short amount of time. In fact, treatment approaches proven to be effective at reducing severe COPD exacerbations are usually not indicated for acute management.

Marin et al [52] built a model to predict inpatient stays for COPD in up to the next 8 years with an AUC of 0.88 and a separate model to predict ED visits for COPD in up to the next 8 years with an AUC of 0.78. An inpatient stay or an ED visit that will happen several years later is too remote to be worth using precious care management resources now to prevent.

For the patients with COPD who will have severe COPD exacerbations in the future, sensitivity is the proportion of patients whom the model identifies. The difference in sensitivity could greatly affect hospital use. Our final model's sensitivity is higher than the sensitivities achieved by the models developed by several other research groups [20-22,25,26,53]. Compared with our final model, the models developed by Orchard et al [24], Faganello et al [27], and Alcázar et al [28] each reached a higher sensitivity at the price of a much lower specificity. For each of these 3 models, if we adjust the cutoff threshold for binary classification and make our final model have the same specificity as that model, our final model would achieve a higher sensitivity than that model. More specifically, at a specificity of $60.02 \%$ (4410/7347), our final model achieved a sensitivity of $90.1 \%$ (164/182), whereas the model developed by Orchard et al [24] achieved a sensitivity of $80 \%$. At a specificity of $73.3 \%(5385 / 7347)$, our final model achieved a sensitivity of $84.1 \%$ (153/182), whereas the model developed by Faganello et al [27] achieved a sensitivity of $58.3 \%$. At a specificity of $77.34 \%$ (5682/7347), our final model achieved a sensitivity of $81.9 \%$ (149/182), whereas the model developed by Alcázar et al [28] achieved a sensitivity of $76.2 \%$.

The prevalence rate of poor outcomes has a large impact on any model's PPV [100]. On our data set, where this prevalence rate is approximately $5 \%$, our final model reached a PPV of $<14 \%$. In comparison, on a data set where this prevalence rate is $11.63 \%$, the model developed by Annavarapu et al [20] reached a PPV of $48.1 \%$. On a data set where this prevalence rate is $6.4 \%$, the model developed by Thomsen et al [23] reached a PPV of $18 \%$. On a data set where this prevalence rate is $39.4 \%$, the model developed by Alcázar et al [28] reached a PPV of $61.5 \%$. In all 3 cases, the higher prevalence rates of poor outcomes permitted the PPV to be larger.

Our data set is imbalanced, with only a small portion of patients to have severe COPD exacerbations in the next year. For imbalanced data sets, the area under the precision-recall curve
(AUPRC) is a better measure of overall model performance than the AUC [101]. The AUPRC was reported for only the model developed by Ställberg et al [53] among all the prior models. Although the model developed by Ställberg et al [53] had an AUC of 0.86, which is only slightly lower than that of our final model, our final model had an AUPRC of 0.24 (95\% CI 0.18-0.31) that is 3 times as large as the 0.08 AUPRC of that model. In addition, that model predicted COPD-related inpatient stays, for which COPD can be any of the diagnoses, in the next 10 days. If a patient will incur an inpatient stay in the next 10 days, intervening starting from today could be too late to avoid the inpatient stay. In comparison, our final model predicted ED visits or inpatient stays with a principal diagnosis of COPD in the next year, allowing more lead time for preventive interventions to be effective.

\section{Considerations for Future Clinical Use}

Our final model reached an AUC that is larger than every AUC formerly reported in the literature for predicting severe COPD exacerbations in the next year. Despite having a relatively low PPV, our final model could still benefit health care for 3 reasons.

First, health care systems such as the UWM and Intermountain Healthcare use proprietary models, which have similar performance to the formerly published models, to allocate COPD care management resources. Our final model had a higher AUC than all formerly reported AUCs for predicting severe COPD exacerbations in the next year. Hence, although we plan to investigate using various techniques to further improve model performance in the future, we think it is already worth considering using our final model to replace the proprietary models currently being used at health care systems such as the UWM for COPD care management.

Second, we set the cutoff threshold for binary classification at the top 9.99\% (752/7529) of the patients with the largest predicted risk. In this case, a perfect model would achieve the theoretically maximum possible PPV of $24.2 \%$ (182/752). Our final model's PPV is $56.6 \%$ (103/182) of the theoretically maximum possible PPV. In other words, our final model captured 56.6\% (103/182) of the patients with COPD who would have severe COPD exacerbations in the next year. If we change the cutoff threshold to the top $25 \%$ of the patients with the largest predicted risk, the final model would capture $83 \%$ (151/182) of the patients with COPD who would have severe COPD exacerbations in the next year.

Third, a PPV at the level of our final model's PPV is suitable for identifying patients with COPD and at high risk for low-cost preventive interventions such as arranging a nurse to further follow up with the patient through phone calls, teaching the patient to correctly use a COPD inhaler, teaching the patient the correct use of a peak flow meter to self-monitor symptoms at home, and enrolling the patient in a home-based pulmonary rehabilitation program [102].

Our final model used 229 features. To ease clinical deployment, we could reduce features, for example, to the top 19 with importance values $\geq 1 \%$. A feature's importance value differs across health care systems. If conditions permit, we should use 
a data set from the target health care system to compute the features' importance values and decide which features to retain.

Our final model was based on XGBoost [87], which leverages the hyperparameter scale_pos_weight to balance the weights of the 2 outcome classes in our data set [103]. The scale_pos_weight hyperparameter was set by our automatic model selection method [89] to a nondefault value to maximize our final model's AUC [104]. This caused the side effect of greatly increasing our model's predicted probabilities of having future severe COPD exacerbations to values much larger than the true probabilities [103]. However, it does not affect our ability to identify the top portion of the patients with the largest predicted risk for preventive interventions. If preferred, we could forgo the balancing by keeping scale_pos_weight at its default value 1 . In this case, our model's AUC would drop by 0.003 to 0.863 (95\% CI 0.835-0.888), which is still larger than every formerly published AUC for predicting severe COPD exacerbations in the next year.

\section{Limitations}

This study includes several limitations that are worth future work.

First, this study used solely structured data. It is worth considering performing natural language processing to extract features from unstructured clinical notes to improve model performance. A model with higher performance can be used to better facilitate COPD care management.

Second, this study used age, diagnosis codes, and medication data to identify patients with COPD and used diagnosis codes and encounter information to define the prediction target. One can use age, diagnosis codes, and medication data to identify patients with COPD reasonably well [56]; yet, diagnosis codes were shown to have a low sensitivity in capturing inpatient stays for COPD [105]. Our predictive model is likely to perform poorly at finding those patients who would experience only future inpatient stays for COPD that are not captured by our current definition of the prediction target. We expect that this will not greatly affect our predictive model's usefulness for facilitating COPD care management. On the basis of our current definition of the prediction target, $>5 \%$ of the patients in our data set had severe COPD exacerbations in the following year. If fully captured by the predictive model, these patients would have already exceeded the service capacity of a typical care management program, which can take $\leq 3 \%$ of the patients [17]. In the future, one could consider adding both medication data and information extracted from clinical notes through natural language processing to better capture inpatient stays for COPD.

Third, this study used non-deep learning classification algorithms. Deep learning has improved model performance for many clinical predictive modeling tasks [106-111]. It is worth investigating whether using deep learning can improve model performance for predicting severe COPD exacerbations.

Fourth, this study used data from a single health care system: the UWM. It is worth evaluating our model's generalizability to other health care systems. We are working on obtaining a data set of patients with COPD from Intermountain Healthcare for this purpose [112].

Fifth, our data set contained no information on UWM patients' health care use at other health care systems. It is worth evaluating how our model's performance would change if data on UWM patients' health care use at other health care systems are available.

\section{Conclusions}

This work improved the state of the art of predicting severe COPD exacerbations in patients with COPD. In particular, our final model had a higher AUC than every formerly published model AUC on predicting severe COPD exacerbations in the next year. After improving our model's performance measures further and using our recently published automatic explanation method [95] to automatically explain the model's predictions, our model could be used in a decision support tool to guide the use of care management for patients with COPD and at high risk to improve outcomes.

\section{Acknowledgments}

GL and SZ were partially supported by the National Heart, Lung, and Blood Institute of the National Institutes of Health under award number R01HL142503. SZ was also partially supported by the National Library of Medicine Training Grant under award number T15LM007442. MA was partially supported by grants from the Flight Attendant Medical Research Institute (CIA190001) and the California Tobacco-Related Disease Research Program (T29IR0715). The funders had no role in study design, data collection and analysis, decision to publish, or preparation of the manuscript. YT did the work at the University of Washington when she was a visiting PhD student.

\section{Authors' Contributions}

GL and SZ were mainly responsible for the paper. SZ performed a literature review, extracted and analyzed the data, constructed the models, and wrote the first draft of the paper. GL conceptualized and designed the study, participated in performing data analysis, and rewrote the whole paper. MA and ZCL provided clinical expertise, contributed to conceptualizing the presentation, and revised the paper. YT took part in extracting the data and identifying the biologically implausible values.

\section{Conflicts of Interest}

None declared. 


\section{Multimedia Appendix 1}

The candidate features and the features used in the final model in the main analysis and their importance values. [PDF File (Adobe PDF File), 190 KB-Multimedia Appendix 1]

\section{References}

1. Ford ES, Murphy LB, Khavjou O, Giles WH, Holt JB, Croft JB. Total and state-specific medical and absenteeism costs of COPD among adults aged $\geq 18$ years in the United States for 2010 and projections through 2020. Chest 2015 Jan;147(1):31-45. [doi: 10.1378/chest.14-0972] [Medline: 25058738]

2. Disease or condition of the week - COPD. Centers for Disease Control and Prevention. 2019. URL: https://www.cdc.gov/ dotw/copd/index.html [accessed 2021-12-20]

3. 2020 Gold reports. Global Initiative for Chronic Obstructive Lung Disease - GOLD. 2020. URL: https://goldcopd.org/ gold-reports [accessed 2021-12-20]

4. Blanchette CM, Dalal AA, Mapel D. Changes in COPD demographics and costs over 20 years. J Med Econ 2012;15(6):1176-1182. [doi: 10.3111/13696998.2012.713880] [Medline: 22812689]

5. Anzueto A, Leimer I, Kesten S. Impact of frequency of COPD exacerbations on pulmonary function, health status and clinical outcomes. Int J Chron Obstruct Pulmon Dis 2009;4:245-251 [FREE Full text] [doi: 10.2147/copd.s4862] [Medline: 19657398]

6. Connors Jr AF, Dawson NV, Thomas C, Harrell Jr FE, Desbiens N, Fulkerson WJ, et al. Outcomes following acute exacerbation of severe chronic obstructive lung disease. The SUPPORT investigators (Study to Understand Prognoses and Preferences for Outcomes and Risks of Treatments). Am J Respir Crit Care Med 1996 Oct;154(4 Pt 1):959-967. [doi: 10.1164/ajrccm.154.4.8887592] [Medline: $\underline{8887592]}$

7. Viglio S, Iadarola P, Lupi A, Trisolini R, Tinelli C, Balbi B, et al. MEKC of desmosine and isodesmosine in urine of chronic destructive lung disease patients. Eur Respir J 2000 Jun;15(6):1039-1045 [FREE Full text] [doi: 10.1034/j.1399-3003.2000.01511.x] [Medline: 10885422$]$

8. Kanner RE, Anthonisen NR, Connett JE, Lung Health Study Research Group. Lower respiratory illnesses promote FEV(1) decline in current smokers but not ex-smokers with mild chronic obstructive pulmonary disease: results from the lung health study. Am J Respir Crit Care Med 2001 Aug 01;164(3):358-364. [doi: 10.1164/ajrccm.164.3.2010017] [Medline: 11500333]

9. Spencer S, Jones PW, GLOBE Study Group. Time course of recovery of health status following an infective exacerbation of chronic bronchitis. Thorax 2003 Jul;58(7):589-593 [FREE Full text] [doi: 10.1136/thorax.58.7.589] [Medline: 12832673]

10. Spencer S, Calverley PM, Burge PS, Jones PW, ISOLDE Study Group. Inhaled Steroids in Obstructive Lung Disease. Health status deterioration in patients with chronic obstructive pulmonary disease. Am J Respir Crit Care Med 2001 Jan;163(1):122-128. [doi: 10.1164/ajrccm.163.1.2005009] [Medline: 11208636]

11. Johnston J, Longman J, Ewald D, King J, Das S, Passey M. Study of potentially preventable hospitalisations (PPH) for chronic conditions: what proportion are preventable and what factors are associated with preventable PPH? BMJ Open 2020 Nov 09;10(11):e038415 [FREE Full text] [doi: 10.1136/bmjopen-2020-038415] [Medline: 33168551]

12. Billings J, Zeitel L, Lukomnik J, Carey TS, Blank AE, Newman L. Impact of socioeconomic status on hospital use in New York City. Health Aff (Millwood) 1993;12(1):162-173. [doi: 10.1377/hlthaff.12.1.162] [Medline: $\underline{8509018]}$

13. Mays GP, Claxton G, White J. Managed care rebound? Recent changes in health plans' cost containment strategies. Health Aff (Millwood) 2004;Suppl Web Exclusives:427-436 [FREE Full text] [doi: 10.1377/hlthaff.w4.427] [Medline: 15451964]

14. Rice KL, Dewan N, Bloomfield HE, Grill J, Schult TM, Nelson DB, et al. Disease management program for chronic obstructive pulmonary disease: a randomized controlled trial. Am J Respir Crit Care Med 2010 Oct 1;182(7):890-896. [doi: 10.1164/rccm.200910-15790C] [Medline: 20075385]

15. Bandurska E, Damps-Konstańska I, Popowski P, Jędrzejczyk T, Janowiak P, Swiętnicka K, et al. Impact of integrated care model (ICM) on direct medical costs in management of advanced chronic obstructive pulmonary disease (COPD). Med Sci Monit 2017 Jun 12;23:2850-2862 [FREE Full text] [doi: 10.12659/msm.901982] [Medline: 28603270]

16. Curry N, Billings J, Darin B, Dixon J, Williams M, Wennberg D. Predictive risk project literature review. King's Fund, London. 2005. URL: http://www.kingsfund.org.uk/sites/files/kf/field/field document/ predictive-risk-literature-review-june2005.pdf, [accessed 2021-12-20]

17. Axelrod RC, Vogel D. Predictive modeling in health plans. Dis Manag Health Outcomes 2003;11(12):779-787. [doi: 10.2165/00115677-200311120-00003]

18. Hurst JR, Vestbo J, Anzueto A, Locantore N, Müllerova H, Tal-Singer R, Evaluation of COPD Longitudinally to Identify Predictive Surrogate Endpoints (ECLIPSE) Investigators. Susceptibility to exacerbation in chronic obstructive pulmonary disease. N Engl J Med 2010 Sep 16;363(12):1128-1138. [doi: 10.1056/NEJMoa0909883] [Medline: 20843247]

19. Blagev DP, Collingridge DS, Rea S, Press VG, Churpek MM, Carey K, et al. Stability of frequency of severe chronic obstructive pulmonary disease exacerbations and health care utilization in clinical populations. Chronic Obstr Pulm Dis 2018 Jun 20;5(3):208-220 [FREE Full text] [doi: 10.15326/jcopdf.5.3.2017.0183] [Medline: 30584584] 
20. Annavarapu S, Goldfarb S, Gelb M, Moretz C, Renda A, Kaila S. Development and validation of a predictive model to identify patients at risk of severe COPD exacerbations using administrative claims data. Int J Chron Obstruct Pulmon Dis 2018;13:2121-2130 [FREE Full text] [doi: 10.2147/COPD.S155773] [Medline: 30022818]

21. Tavakoli H, Chen W, Sin DD, FitzGerald JM, Sadatsafavi M. Predicting severe chronic obstructive pulmonary disease exacerbations. Developing a population surveillance approach with administrative data. Ann Am Thorac Soc 2020 Sep;17(9):1069-1076. [doi: 10.1513/AnnalsATS.202001-070OC] [Medline: $\underline{32383971]}$

22. Samp JC, Joo MJ, Schumock GT, Calip GS, Pickard AS, Lee TA. Predicting acute exacerbations in chronic obstructive pulmonary disease. J Manag Care Spec Pharm 2018 Mar;24(3):265-279. [doi: 10.18553/jmcp.2018.24.3.265] [Medline: 29485951]

23. Thomsen M, Ingebrigtsen TS, Marott JL, Dahl M, Lange P, Vestbo J, et al. Inflammatory biomarkers and exacerbations in chronic obstructive pulmonary disease. J Am Med Assoc 2013 Jun 12;309(22):2353-2361. [doi: 10.1001/jama.2013.5732] [Medline: 23757083]

24. Orchard P, Agakova A, Pinnock H, Burton CD, Sarran C, Agakov F, et al. Improving prediction of risk of hospital admission in chronic obstructive pulmonary disease: application of machine learning to telemonitoring data. J Med Internet Res 2018 Sep 21;20(9):e263 [FREE Full text] [doi: 10.2196/jmir.9227] [Medline: 30249589]

25. Suetomo M, Kawayama T, Kinoshita T, Takenaka S, Matsuoka M, Matsunaga K, et al. COPD assessment tests scores are associated with exacerbated chronic obstructive pulmonary disease in Japanese patients. Respir Investig 2014 Sep;52(5):288-295. [doi: 10.1016/j.resinv.2014.04.004] [Medline: 25169844]

26. Lee SD, Huang MS, Kang J, Lin CH, Park MJ, Oh YM, Investigators of the Predictive Ability of CAT in Acute Exacerbations of COPD (PACE) Study. The COPD assessment test (CAT) assists prediction of COPD exacerbations in high-risk patients. Respir Med 2014 Apr;108(4):600-608 [FREE Full text] [doi: 10.1016/j.rmed.2013.12.014] [Medline: 24456695]

27. Faganello MM, Tanni SE, Sanchez FF, Pelegrino NR, Lucheta PA, Godoy I. BODE index and GOLD staging as predictors of 1-year exacerbation risk in chronic obstructive pulmonary disease. Am J Med Sci 2010 Jan;339(1):10-14. [doi: 10.1097/MAJ.0b013e3181bb8111] [Medline: 19926966]

28. Alcázar B, García-Polo C, Herrejón A, Ruiz LA, de Miguel J, Ros JA, et al. Factors associated with hospital admission for exacerbation of chronic obstructive pulmonary disease. Arch Bronconeumol 2012 Mar;48(3):70-76. [doi: 10.1016/j.arbres.2011.10.009] [Medline: 22196478]

29. Bertens LC, Reitsma JB, Moons KG, van Mourik Y, Lammers JW, Broekhuizen BD, et al. Development and validation of a model to predict the risk of exacerbations in chronic obstructive pulmonary disease. Int J Chron Obstruct Pulmon Dis 2013;8:493-499 [FREE Full text] [doi: 10.2147/COPD.S49609] [Medline: 24143086]

30. Miravitlles M, Guerrero T, Mayordomo C, Sánchez-Agudo L, Nicolau F, Segú JL. Factors associated with increased risk of exacerbation and hospital admission in a cohort of ambulatory COPD patients: a multiple logistic regression analysis. The EOLO Study Group. Respiration 2000;67(5):495-501. [doi: 10.1159/000067462] [Medline: 11070451]

31. Make BJ, Eriksson G, Calverley PM, Jenkins CR, Postma DS, Peterson S, et al. A score to predict short-term risk of COPD exacerbations (SCOPEX). Int J Chron Obstruct Pulmon Dis 2015;10:201-209 [FREE Full text] [doi: 10.2147/COPD.S69589] [Medline: 25670896$]$

32. Montserrat-Capdevila J, Godoy P, Marsal JR, Barbé F. Predictive model of hospital admission for COPD exacerbation. Respir Care 2015 Sep;60(9):1288-1294 [FREE Full text] [doi: 10.4187/respcare.04005] [Medline: 26286737]

33. Kerkhof M, Freeman D, Jones R, Chisholm A, Price DB, Respiratory Effectiveness Group. Predicting frequent COPD exacerbations using primary care data. Int J Chron Obstruct Pulmon Dis 2015;10:2439-2450 [FREE Full text] [doi: 10.2147/COPD.S94259] [Medline: 26609229]

34. Chen X, Wang Q, Hu Y, Zhang L, Xiong W, Xu Y, et al. A nomogram for predicting severe exacerbations in stable COPD patients. Int J Chron Obstruct Pulmon Dis 2020;15:379-388 [FREE Full text] [doi: 10.2147/COPD.S234241] [Medline: 32110006]

35. Yii AC, Loh CH, Tiew PY, Xu H, Taha AA, Koh J, et al. A clinical prediction model for hospitalized COPD exacerbations based on "treatable traits". Int J Chron Obstruct Pulmon Dis 2019;14:719-728 [FREE Full text] [doi: 10.2147/COPD.S194922] [Medline: $\underline{30988606}$ ]

36. Adibi A, Sin DD, Safari A, Johnson KM, Aaron SD, FitzGerald JM, et al. The Acute COPD Exacerbation Prediction Tool (ACCEPT): a modelling study. Lancet Respir Med 2020 Oct;8(10):1013-1021. [doi: 10.1016/S2213-2600(19)30397-2] [Medline: $\underline{\text { 32178776] }}$

37. Stanford RH, Nag A, Mapel DW, Lee TA, Rosiello R, Vekeman F, et al. Validation of a new risk measure for chronic obstructive pulmonary disease exacerbation using health insurance claims data. Ann Am Thorac Soc 2016 Jul;13(7):1067-1075. [doi: 10.1513/AnnalsATS.201508-493OC] [Medline: 27070274]

38. Stanford RH, Nag A, Mapel DW, Lee TA, Rosiello R, Schatz M, et al. Claims-based risk model for first severe COPD exacerbation. Am J Manag Care 2018 Feb 1;24(2):45-53 [FREE Full text] [Medline: 29461849]

39. Stanford RH, Lau MS, Li Y, Stemkowski S. External validation of a COPD risk measure in a commercial and Medicare population: the COPD treatment ratio. J Manag Care Spec Pharm 2019 Jan;25(1):58-69. [doi: 10.18553/jmcp.2019.25.1.058] [Medline: 30589629] 
40. Stanford RH, Korrer S, Brekke L, Reinsch T, Bengtson LG. Validation and assessment of the COPD treatment ratio as a predictor of severe exacerbations. Chronic Obstr Pulm Dis 2020 Jan;7(1):38-48 [FREE Full text] [doi: 10.15326/jcopdf.7.1.2019.0132] [Medline: 31999901]

41. Jones RC, Donaldson GC, Chavannes NH, Kida K, Dickson-Spillmann M, Harding S, et al. Derivation and validation of a composite index of severity in chronic obstructive pulmonary disease: the DOSE Index. Am J Respir Crit Care Med 2009 Dec 15;180(12):1189-1195. [doi: 10.1164/rccm.200902-02710C] [Medline: 19797160]

42. Jones RC, Price D, Chavannes NH, Lee AJ, Hyland ME, Ställberg B, UNLOCK Group of the IPCRG. Multi-component assessment of chronic obstructive pulmonary disease: an evaluation of the ADO and DOSE indices and the global obstructive lung disease categories in international primary care data sets. NPJ Prim Care Respir Med 2016 Apr 07;26:16010 [FREE Full text] [doi: 10.1038/npjpcrm.2016.10] [Medline: 27053297]

43. Fan VS, Curtis JR, Tu SP, McDonell MB, Fihn SD, Ambulatory Care Quality Improvement Project Investigators. Using quality of life to predict hospitalization and mortality in patients with obstructive lung diseases. Chest 2002 Aug;122(2):429-436. [doi: 10.1378/chest.122.2.429] [Medline: 12171813]

44. Moy ML, Teylan M, Danilack VA, Gagnon DR, Garshick E. An index of daily step count and systemic inflammation predicts clinical outcomes in chronic obstructive pulmonary disease. Ann Am Thorac Soc 2014 Feb;11(2):149-157. [doi: 10.1513/AnnalsATS.201307-2430C] [Medline: 24308588]

45. Briggs A, Spencer M, Wang H, Mannino D, Sin DD. Development and validation of a prognostic index for health outcomes in chronic obstructive pulmonary disease. Arch Intern Med 2008 Jan 14;168(1):71-79. [doi: 10.1001/archinternmed.2007.37] [Medline: 18195198$]$

46. Lange P, Marott JL, Vestbo J, Olsen KR, Ingebrigtsen TS, Dahl M, et al. Prediction of the clinical course of chronic obstructive pulmonary disease, using the new GOLD classification: a study of the general population. Am J Respir Crit Care Med 2012 Nov 15;186(10):975-981. [doi: 10.1164/rccm.201207-12990C] [Medline: 22997207]

47. Abascal-Bolado B, Novotny PJ, Sloan JA, Karpman C, Dulohery MM, Benzo RP. Forecasting COPD hospitalization in the clinic: optimizing the chronic respiratory questionnaire. Int J Chron Obstruct Pulmon Dis 2015;10:2295-2301 [FREE Full text] [doi: 10.2147/COPD.S87469] [Medline: 26543362]

48. Blanco-Aparicio M, Vázquez I, Pita-Fernández S, Pértega-Diaz S, Verea-Hernando H. Utility of brief questionnaires of health-related quality of life (Airways Questionnaire 20 and Clinical COPD Questionnaire) to predict exacerbations in patients with asthma and COPD. Health Qual Life Outcomes 2013 May 27;11:85 [FREE Full text] [doi:

10.1186/1477-7525-11-85] [Medline: 23706146]

49. Yoo JW, Hong Y, Seo JB, Chae EJ, Ra SW, Lee JH, et al. Comparison of clinico-physiologic and CT imaging risk factors for COPD exacerbation. J Korean Med Sci 2011 Dec;26(12):1606-1612 [FREE Full text] [doi: 10.3346/jkms.2011.26.12.1606] [Medline: 22147998]

50. Niewoehner DE, Lokhnygina Y, Rice K, Kuschner WG, Sharafkhaneh A, Sarosi GA, et al. Risk indexes for exacerbations and hospitalizations due to COPD. Chest 2007 Jan;131(1):20-28. [doi: 10.1378/chest.06-1316] [Medline: 17218552]

51. Austin PC, Stanbrook MB, Anderson GM, Newman A, Gershon AS. Comparative ability of comorbidity classification methods for administrative data to predict outcomes in patients with chronic obstructive pulmonary disease. Ann Epidemiol 2012 Dec;22(12):881-887 [FREE Full text] [doi: 10.1016/j.annepidem.2012.09.011] [Medline: 23121992]

52. Marin JM, Carrizo SJ, Casanova C, Martinez-Camblor P, Soriano JB, Agusti AG, et al. Prediction of risk of COPD exacerbations by the BODE index. Respir Med 2009 Mar;103(3):373-378 [FREE Full text] [doi: 10.1016/j.rmed.2008.10.004] [Medline: 19013781]

53. Ställberg B, Lisspers K, Larsson K, Janson C, Müller M, Łuczko M, et al. Predicting hospitalization due to COPD exacerbations in Swedish primary care patients using machine learning - based on the ARCTIC study. Int J Chron Obstruct Pulmon Dis 2021;16:677-688 [FREE Full text] [doi: 10.2147/COPD.S293099] [Medline: 33758504$]$

54. Tong Y, Liao ZC, Tarczy-Hornoch P, Luo G. Using a constraint-based method to identify chronic disease patients who are apt to obtain care mostly within a given health care system: retrospective cohort study. JMIR Form Res 2021 Oct 07;5(10):e26314 [FREE Full text] [doi: 10.2196/26314] [Medline: 34617906]

55. NQF \#1891 Hospital 30-day, all-cause, risk-standardized readmission rate (RSRR) following chronic obstructive pulmonary disease (COPD) hospitalization. National Quality Forum. 2012. URL: http://www.qualityforum.org/Projects/n-r/ Pulmonary_Endorsement_Maintenance/1891_30_Day_RSRR_COPD.aspx [accessed 2021-12-19]

56. Cooke CR, Joo MJ, Anderson SM, Lee TA, Udris EM, Johnson E, et al. The validity of using ICD-9 codes and pharmacy records to identify patients with chronic obstructive pulmonary disease. BMC Health Serv Res 2011 Feb 16;11:37 [FREE Full text] [doi: 10.1186/1472-6963-11-37] [Medline: 21324188]

57. Nguyen HQ, Chu L, Amy Liu IL, Lee JS, Suh D, Korotzer B, et al. Associations between physical activity and 30-day readmission risk in chronic obstructive pulmonary disease. Ann Am Thorac Soc 2014 Jun;11(5):695-705. [doi: 10.1513/AnnalsATS.201401-0170C] [Medline: 24713094]

58. Lindenauer PK, Grosso LM, Wang C, Wang Y, Krishnan JA, Lee TA, et al. Development, validation, and results of a risk-standardized measure of hospital 30-day mortality for patients with exacerbation of chronic obstructive pulmonary disease. J Hosp Med 2013 Aug;8(8):428-435. [doi: 10.1002/jhm.2066] [Medline: 23913593] 
59. Qureshi H, Sharafkhaneh A, Hanania NA. Chronic obstructive pulmonary disease exacerbations: latest evidence and clinical implications. Ther Adv Chronic Dis 2014 Sep;5(5):212-227 [FREE Full text] [doi: 10.1177/2040622314532862] [Medline: $\underline{25177479]}$

60. Müllerova H, Maselli DJ, Locantore N, Vestbo J, Hurst JR, Wedzicha JA, et al. Hospitalized exacerbations of COPD: risk factors and outcomes in the ECLIPSE cohort. Chest 2015 Apr;147(4):999-1007. [doi: 10.1378/chest.14-0655] [Medline: 25356881]

61. Donaldson GC, Seemungal TA, Bhowmik A, Wedzicha JA. Relationship between exacerbation frequency and lung function decline in chronic obstructive pulmonary disease. Thorax 2002 Oct;57(10):847-852 [FREE Full text] [doi: 10.1136/thorax.57.10.847] [Medline: $\underline{12324669]}$

62. Hurst JR, Donaldson GC, Quint JK, Goldring JJ, Baghai-Ravary R, Wedzicha JA. Temporal clustering of exacerbations in chronic obstructive pulmonary disease. Am J Respir Crit Care Med 2009 Mar 01;179(5):369-374. [doi:

10.1164/rccm.200807-10670C] [Medline: 19074596]

63. Similowski T, Agustí A, MacNee W, Schönhofer B. The potential impact of anaemia of chronic disease in COPD. Eur Respir J 2006 Feb;27(2):390-396 [FREE Full text] [doi: 10.1183/09031936.06.00143704] [Medline: 16452598 ]

64. Dahl M, Vestbo J, Lange P, Bojesen SE, Tybjaerg-Hansen A, Nordestgaard BG. C-reactive protein as a predictor of prognosis in chronic obstructive pulmonary disease. Am J Respir Crit Care Med 2007 Feb 1;175(3):250-255. [doi:

10.1164/rccm.200605-7130C] [Medline: 17053205 ]

65. Hoenderdos K, Condliffe A. The neutrophil in chronic obstructive pulmonary disease. Am J Respir Cell Mol Biol 2013 May;48(5):531-539. [doi: 10.1165/rcmb.2012-0492TR] [Medline: 23328639]

66. Lonergan M, Dicker AJ, Crichton ML, Keir HR, Van Dyke MK, Mullerova H, et al. Blood neutrophil counts are associated with exacerbation frequency and mortality in COPD. Respir Res 2020 Jul 01;21(1):166 [FREE Full text] [doi:

10.1186/s12931-020-01436-7] [Medline: 32611352]

67. Chambellan A, Chailleux E, Similowski T, ANTADIR Observatory Group. Prognostic value of the hematocrit in patients with severe COPD receiving long-term oxygen therapy. Chest 2005 Sep;128(3):1201-1208. [doi: 10.1378/chest.128.3.1201] [Medline: 16162707$]$

68. Toft-Petersen AP, Torp-Pedersen C, Weinreich UM, Rasmussen BS. Association between hemoglobin and prognosis in patients admitted to hospital for COPD. Int J Chron Obstruct Pulmon Dis 2016;11:2813-2820 [FREE Full text] [doi: 10.2147/COPD.S116269] [Medline: 27877035]

69. van Dijk EJ, Vermeer SE, de Groot JC, van de Minkelis J, Prins ND, Oudkerk M, et al. Arterial oxygen saturation, COPD, and cerebral small vessel disease. J Neurol Neurosurg Psychiatry 2004 May;75(5):733-736 [FREE Full text] [doi: 10.1136/jnnp.2003.022012] [Medline: 15090569]

70. Kessler R, Faller M, Fourgaut G, Mennecier B, Weitzenblum E. Predictive factors of hospitalization for acute exacerbation in a series of 64 patients with chronic obstructive pulmonary disease. Am J Respir Crit Care Med 1999 Jan;159(1):158-164. [doi: 10.1164/ajrccm.159.1.9803117] [Medline: 9872834]

71. Fermont JM, Masconi KL, Jensen MT, Ferrari R, Di Lorenzo VA, Marott JM, et al. Biomarkers and clinical outcomes in COPD: a systematic review and meta-analysis. Thorax 2019 May;74(5):439-446 [FREE Full text] [doi: 10.1136/thoraxjnl-2018-211855] [Medline: 30617161]

72. Halpin DM, Miravitlles M, Metzdorf N, Celli B. Impact and prevention of severe exacerbations of COPD: a review of the evidence. Int J Chron Obstruct Pulmon Dis 2017;12:2891-2908 [FREE Full text] [doi: 10.2147/COPD.S139470] [Medline: 29062228]

73. The world's oldest people and their secrets to a long life. Guinness World Records. 2020. URL: https://www. guinnessworldrecords.com/news/2020/10/the-worlds-oldest-people-and-their-secrets-to-a-long-life-632895 [accessed 2021-12-20]

74. Lightest birth. Guinness World Records. 2020. URL: https://www.guinnessworldrecords.com/world-records/lightest-birth [accessed 2021-12-20]

75. Heaviest man ever. Guinness World Records. 2020. URL: https://www.guinnessworldrecords.com/world-records/heaviest-man [accessed 2021-12-20]

76. Shortest baby. Guinness World Records. 2020. URL: https://www.guinnessworldrecords.com/world-records/shortest-baby [accessed 2021-12-20]

77. Tallest man ever. Guinness World Records. 2020. URL: https://www.guinnessworldrecords.com/world-records/ tallest-man-ever [accessed 2021-12-20]

78. Gwyneth O. Part V Fat: no more fear, no more contempt. The Eating Disorder Institute. 2011. URL: https://edinstitute.org/ blog/2011/12/8/part-v-fat-no-more-fear-no-more-contempt [accessed 2021-12-20]

79. List of heaviest people. Wikipedia. 2021. URL: https://en.wikipedia.org/w/index. php?title=List_of_heaviest_people\&oldid=1000662342 [accessed 2021-12-20]

80. Hankinson JL, Odencrantz JR, Fedan KB. Spirometric reference values from a sample of the general U.S. population. Am J Respir Crit Care Med 1999 Jan;159(1):179-187. [doi: 10.1164/ajrccm.159.1.9712108] [Medline: 9872837]

81. Pellegrino R, Viegi G, Brusasco V, Crapo RO, Burgos F, Casaburi R, et al. Interpretative strategies for lung function tests. Eur Respir J 2005 Nov;26(5):948-968 [FREE Full text] [doi: 10.1183/09031936.05.00035205] [Medline: 16264058] 
82. Marion MS, Leonardson GR, Rhoades ER, Welty TK, Enright PL. Spirometry reference values for American Indian adults: results from the Strong Heart Study. Chest 2001 Aug;120(2):489-495. [doi: 10.1378/chest.120.2.489] [Medline: 11502648]

83. Bronchodilators. National Jewish Health. 2018. URL: https://nationaljewish.org/conditions/medications/copd/bronchodilators [accessed 2021-12-19]

84. Luo G, He S, Stone BL, Nkoy FL, Johnson MD. Developing a model to predict hospital encounters for asthma in asthmatic patients: secondary analysis. JMIR Med Inform 2020 Jan 21;8(1):e16080 [FREE Full text] [doi: 10.2196/16080] [Medline: 31961332]

85. Tong Y, Messinger AI, Wilcox AB, Mooney SD, Davidson GH, Suri P, et al. Forecasting future asthma hospital encounters of patients with asthma in an academic health care system: predictive model development and secondary analysis study. $\mathrm{J}$ Med Internet Res 2021 Apr 16;23(4):e22796 [FREE Full text] [doi: 10.2196/22796] [Medline: 33861206]

86. Witten IH, Frank E, Hall MA, Pal CJ. Data Mining: Practical Machine Learning Tools and Techniques, 4th ed. Burlington, MA: Morgan Kaufmann; 2016.

87. Chen T, Guestrin C. XGBoost: a scalable tree boosting system. In: Proceedings of the ACM SIGKDD International Conference on Knowledge Discovery and Data Mining. 2016 Presented at: KDD'16; August 13-17, 2016; San Francisco, CA p. 785-794. [doi: 10.1145/2939672.2939785]

88. XGBoost JVM package. 2021. URL: https://xgboost.readthedocs.io/en/latest/jvm/index.html [accessed 2021-12-20]

89. Zeng X, Luo G. Progressive sampling-based Bayesian optimization for efficient and automatic machine learning model selection. Health Inf Sci Syst 2017 Dec;5(1):2 [FRE Full text] [doi: 10.1007/s13755-017-0023-z] [Medline: 29038732]

90. Thornton C, Hutter F, Hoos HH, Leyton-Brown K. Auto-WEKA: combined selection and hyperparameter optimization of classification algorithms. In: Proceedings of the ACM SIGKDD International Conference on Knowledge Discovery and Data Mining. 2013 Presented at: KDD'13; August 11-14, 2013; Chicago, IL p. 847-855. [doi: 10.1145/2487575.2487629]

91. Steyerberg EW. Clinical Prediction Models: A Practical Approach to Development, Validation, and Updating, 2nd ed. New York, NY: Springer; 2019.

92. Sykes DL, Faruqi S, Holdsworth L, Crooks MG. Impact of COVID-19 on COPD and asthma admissions, and the pandemic from a patient's perspective. ERJ Open Res 2021 Feb 8;7(1) [FREE Full text] [doi: 10.1183/23120541.00822-2020] [Medline: 33575313]

93. Agresti A. Categorical Data Analysis, 3rd ed. Hoboken, NJ: Wiley; 2012.

94. Hastie T, Tibshirani R, Friedman J. The Elements of Statistical Learning: Data Mining, Inference, and Prediction, 2nd ed. New York, NY: Springer; 2016.

95. Luo G, Johnson MD, Nkoy FL, He S, Stone BL. Automatically explaining machine learning prediction results on asthma hospital visits in patients with asthma: secondary analysis. JMIR Med Inform 2020 Dec 31;8(12):e21965 [FREE Full text] [doi: 10.2196/21965] [Medline: 33382379]

96. Guerra B, Gaveikaite V, Bianchi C, Puhan MA. Prediction models for exacerbations in patients with COPD. Eur Respir Rev 2017 Jan 17;26(143):160061 [FREE Full text] [doi: 10.1183/16000617.0061-2016] [Medline: 28096287]

97. Bellou V, Belbasis L, Konstantinidis AK, Tzoulaki I, Evangelou E. Prognostic models for outcome prediction in patients with chronic obstructive pulmonary disease: systematic review and critical appraisal. Br Med J 2019 Oct 4;367:15358 [FREE Full text] [doi: 10.1136/bmj.15358] [Medline: 31585960]

98. Longman JM, Passey ME, Ewald DP, Rix E, Morgan GG. Admissions for chronic ambulatory care sensitive conditions a useful measure of potentially preventable admission? BMC Health Serv Res 2015 Oct 16;15:472 [FREE Full text] [doi: 10.1186/s12913-015-1137-0] [Medline: 26475293]

99. Johnston JJ, Longman JM, Ewald DP, Rolfe MI, Alvarez SD, Gilliland AH, et al. Validity of a tool designed to assess the preventability of potentially preventable hospitalizations for chronic conditions. Fam Pract 2020 Jul 23;37(3):390-394 [FREE Full text] [doi: 10.1093/fampra/cmz086] [Medline: $\underline{31848589]}$

100. Ranganathan P, Aggarwal R. Common pitfalls in statistical analysis: understanding the properties of diagnostic tests - Part 1. Perspect Clin Res 2018;9(1):40-43 [FREE Full text] [doi: 10.4103/picr.PICR 170 17] [Medline: 29430417]

101. Davis J, Goadrich M. The relationship between precision-recall and ROC curves. In: Proceedings of the $23 \mathrm{rd}$ International Conference on Machine Learning. 2006 Presented at: ICML'06; June 25-29, 2006; Pittsburgh, PA p. 233-240. [doi: 10.1145/1143844.1143874]

102. Burge AT, Holland AE, McDonald CF, Abramson MJ, Hill CJ, Lee AL, et al. Home-based pulmonary rehabilitation for COPD using minimal resources: an economic analysis. Respirology 2020 Feb;25(2):183-190. [doi: 10.1111/resp.13667] [Medline: $\underline{31418515]}$

103. XGBoost Parameters. 2021. URL: https://xgboost.readthedocs.io/en/latest/parameter.html [accessed 2021-12-20]

104. Notes on Parameter Tuning. 2021. URL: https://xgboost.readthedocs.io/en/latest/tutorials/param tuning.html [accessed 2021-12-20]

105. Stein BD, Bautista A, Schumock GT, Lee TA, Charbeneau JT, Lauderdale DS, et al. The validity of International Classification of Diseases, Ninth Revision, Clinical Modification diagnosis codes for identifying patients hospitalized for COPD exacerbations. Chest 2012 Jan;141(1):87-93 [FREE Full text] [doi: 10.1378/chest.11-0024] [Medline: 21757568]

106. Rajkomar A, Oren E, Chen K, Dai AM, Hajaj N, Hardt M, et al. Scalable and accurate deep learning with electronic health records. NPJ Digit Med 2018 May 8;1:18 [FREE Full text] [doi: 10.1038/s41746-018-0029-1] [Medline: $\underline{\text { 31304302] }}$ 
107. Lipton ZC, Kale DC, Elkan C, Wetzel RC. Learning to diagnose with LSTM recurrent neural networks. In: Proceedings of the International Conference on Learning Representations. 2016 Presented at: International Conference on Learning Representations; May 2-4, 2016; San Juan, Puerto Rico p. 1-18 URL: https://arxiv.org/abs/1511.03677

108. Kam HJ, Kim HY. Learning representations for the early detection of sepsis with deep neural networks. Comput Biol Med 2017 Dec 01;89:248-255. [doi: 10.1016/j.compbiomed.2017.08.015] [Medline: 28843829]

109. Razavian N, Marcus J, Sontag D. Multi-task prediction of disease onsets from longitudinal laboratory tests. In: Proceedings of the Machine Learning in Health Care Conference. 2016 Presented at: Machine Learning in Health Care Conference; August 19-20, 2016; Los Angeles, CA p. 73-100 URL: http://proceedings.mlr.press/v56/Razavian16.html

110. Ching T, Himmelstein DS, Beaulieu-Jones BK, Kalinin AA, Do BT, Way GP, et al. Opportunities and obstacles for deep learning in biology and medicine. J R Soc Interface 2018 Apr;15(141):20170387 [FREE Full text] [doi: 10.1098/rsif.2017.0387] [Medline: 29618526]

111. Shickel B, Tighe PJ, Bihorac A, Rashidi P. Deep EHR: a survey of recent advances in deep learning techniques for Electronic Health Record (EHR) analysis. IEEE J Biomed Health Inform 2018 Dec;22(5):1589-1604. [doi: 10.1109/JBHI.2017.2767063] [Medline: 29989977]

112. Luo G, Stone BL, Koebnick C, He S, Au DH, Sheng X, et al. Using temporal features to provide data-driven clinical early warnings for chronic obstructive pulmonary disease and asthma care management: protocol for a secondary analysis. JMIR Res Protoc 2019 Jun 06;8(6):e13783 [FREE Full text] [doi: 10.2196/13783] [Medline: 31199308]

\author{
Abbreviations \\ AUC: area under the receiver operating characteristic curve \\ AUPRC: area under the precision-recall curve \\ COPD: chronic obstructive pulmonary disease \\ ED: emergency department \\ LABA: long-acting beta- 2 agonist \\ LAMA: long-acting muscarinic antagonist \\ NPV: negative predictive value \\ PCP: primary care provider \\ PPV: positive predictive value \\ UWM: University of Washington Medicine \\ WEKA: Waikato Environment for Knowledge Analysis \\ XGBoost: Extreme Gradient Boosting
}

Edited by G Eysenbach; submitted 03.04.21; peer-reviewed by V Press, P Orchard; comments to author 28.06.21; revised version
received 03.07.21; accepted 19.11.21; published 06.01.22
Please cite as:
Zeng S, Arjomandi M, Tong Y, Liao ZC, Luo G
Developing a Machine Learning Model to Predict Severe Chronic Obstructive Pulmonary Disease Exacerbations: Retrospective
Cohort Study
J Med Internet Res 2022;24(1):e28953
URL: $\underline{\text { https://www.jmir.org/2022/1/e28953 }}$
doi: $10.2196 / 28953$
PMID:

(C) Siyang Zeng, Mehrdad Arjomandi, Yao Tong, Zachary C Liao, Gang Luo. Originally published in the Journal of Medical Internet Research (https://www.jmir.org), 06.01.2022. This is an open-access article distributed under the terms of the Creative Commons Attribution License (https://creativecommons.org/licenses/by/4.0/), which permits unrestricted use, distribution, and reproduction in any medium, provided the original work, first published in the Journal of Medical Internet Research, is properly cited. The complete bibliographic information, a link to the original publication on https://www.jmir.org/, as well as this copyright and license information must be included. 